\title{
25. LATE CENOZOIC CHANGES IN FLUX RATES AND COMPOSITION OF ORGANIC CARBON AT SITES 798 AND 799 (SEA OF JAPAN) ${ }^{1}$
}

\author{
R. Stein ${ }^{2}$ and R. Stax ${ }^{2}$
}

\begin{abstract}
Organic geochemical and sedimentological investigations have been performed on sediments from ODP Sites 798 and 799 in order to reconstruct the depositional environment in the Japan Sea through late Cenozoic times. The Miocene to Quaternary sediments from Site 798 (Oki Ridge) and Site 799 (Kita-Yamato Trough) are characterized by high organic carbon contents of up to $6 \%$. The organic matter is mainly a mixture of marine and terrigenous material. The dominant factors controlling marine organic carbon enrichment in the sediments of Hole 798A are probably an increased surface-water productivity and/or an increased preservation rate of organic carbon under anoxic deep-water conditions. In lower Pliocene sediments at Site 798 and Miocene to Quaternary sediments at Site 799, rapid burial of organic matter in turbidites may have been important, too. Remarkable cycles of dark, laminated sediments distinctly enriched in (marine) organic carbon by up to $5 \%$ and light, bioturbated to homogeneous sediments with reduced organic carbon contents indicate dramatic short-term paleoenvironmental variation.
\end{abstract}

\section{INTRODUCTION}

During Ocean Drilling Program (ODP) Leg 128, Sites 798 and 799 (Fig. 1) were drilled on Oki Ridge and in the Kita-Yamato Trough, respectively (Ingle, Suyehiro, von Breymann, et al., 1990). The primary objective at Site 798 was to obtain a Miocene to Quaternary carbonate-rich sequence, which would provide a high-resolution paleontologic, isotopic, and sedimentologic record. Of major interest were reconstructions of (1) surface- and intermediate-water history including changes in surface-water productivity, dissolved oxygen content of deep-water masses, and the carbonate compensation depth (CCD), (2) changes from anoxic to oxic conditions known to have occurred during Miocene to Pliocene times (Ingle, 1975; Matoba, 1984), and (3) faunal and sedimentary responses to the tectonic evolution of the Japan Sea. The main objective at Site 799 was to reconstruct the depositional and tectonic history of the Kita-Yamato Trough as a typical environment for massive sulfide mineralization in a rifted continental-arc setting.

At both Sites 798 and 799 , organic-carbon-rich sediments were deposited. Thus, these sites are of major interest for studies of the mechanisms controlling the formation of organic-carbon-rich sediments in a marginal sea environment that occasionally was restricted from the normal open-ocean environment (cf. Ingle, 1975; Matoba, 1984).

\section{RECENT AND SUBRECENT ENVIRONMENT IN THE JAPAN SEA}

The Japan Sea is a semiclosed backarc basin with maximum water depths of about $3600 \mathrm{~m}$ (Fig. 2). It is separated into several major basins by topographic highs, which are continental fragments or tectonic ridges. The ages of formation of these basins were estimated from sediment stratigraphy, basement depth, and heat-flow data to vary between 30 and $10 \mathrm{Ma}$ (Tamaki, 1985, 1988). Connection to the marginal seas to the north and south and to the western Pacific is restricted to the shallow Tsushima Strait ( $140 \mathrm{~m}$ water depth), Tsugaru Strait (130 m), Soya Strait (55 m), and Tartary Strait (15 m) (Fig. 2; Ingle, 1975; Matoba, 1984).

Modern surface-water circulation in the Japan Sea is dominated by the inflow of warm and highly saline water through the Tsushima

\footnotetext{
${ }^{1}$ Pisciotto, K. A., Ingle, J. C., Jr., von Breymann, M. T., Barron, J., et al., 1992. Proc. $O D P_{2}$ Sci. Results, 127/128, Pt. 1: College Station, TX (Ocean Drilling Program).

${ }^{2}$ Alfred-Wegener-Institute for Polar and Marine Research, Columbusstrasse, D-2850 Bremerhaven, Federal Republic of Germany.
}

Strait (Tsushima Current, a branch of the Kuroshio Current), the inflow of cold water of low salinity from the north (Liman Current), and the outflow of water masses through the Tsugaru Strait and Soya Strait into the western Pacific (Fig. 2). The modern deep water of the Japan Sea ("Japan Sea Proper Water") forms in the northwestern coastal areas during winter as a result of the cooling and freezing of surface water. The resulting water masses are of higher density and sink to the seafloor (Fig. 2). This intense thermohaline circulation results in sufficient ventilation of the deep-water sphere; the dissolved oxygen content at all depths exceeds $5 \mathrm{~mL} / \mathrm{L}$ (Matoba, 1984). Because of these oxidizing oceanographic conditions, the organic carbon content of the surface sediments is unusually low (Ingle, 1975).

The environmental conditions, however, must have changed dramatically during late Pleistocene to Holocene times, as indicated by piston-core data. During glacial intervals (i.e., times of distinctly lowered sea level), the Japan Sea was probably completely isolated from the Pacific Ocean. The expansion and duration of sea ice coverage, loss of exchange with the Pacific Ocean, and sluggish bottom-water circulation may have caused anoxic deep-water conditions that allowed the formation of framboidal pyrite and organic-carbon-rich sediments (Kobayashi and Nomura, 1972; Ujiie and Ichikura, 1973; Ingle, 1975; Oba, 1983; Oba et al., 1991).

\section{GEOLOGIC SETTING AND SEDIMENTS AT ODP SITES}

Site $798\left(37.04^{\circ} \mathrm{N}, 134.80^{\circ} \mathrm{E}\right.$; water depth, $\left.903 \mathrm{~m}\right)$ is located in the southeastern Japan Sea, about $160 \mathrm{~km}$ north of the western coast of Honshu in a small sediment-filled graben on top of Oki Ridge (Fig. 1). This shallow-water position well above the modern CCD (1500-2200 m; Ujiie and Ichikura, 1973) and on a structurally isolated high was chosen to obtain a carbonate-rich sequence undiluted by coarse-grained gravity-flow sediments common to basinal areas (Ingle, Suyehiro, von Breymann, et al., 1990). At Site 798, a 517 -m-thick pelagic to hemipelagic sediment sequence of early Pliocene to Holocene age was drilled (Ingle, Suyehiro, von Breymann, et al., 1990). The sediments consist mainly of diatomaceous ooze, diatomaceous clay, silty clay, clay, and siliceous claystone, with foraminifers and calcareous nannofossils common in the upper $220 \mathrm{~m}$ of the sequence. This upper part is further characterized by rhythmic changes between dark, laminated, diatom- and organic-carbon-rich intervals and light, homogeneous to intensely bioturbated, clay-rich intervals. Volcanic ash layers are common, with a maximum occurrence in the section dated between 0.9 and $0.3 \mathrm{Ma}$ (Ingle, Suyehiro, 


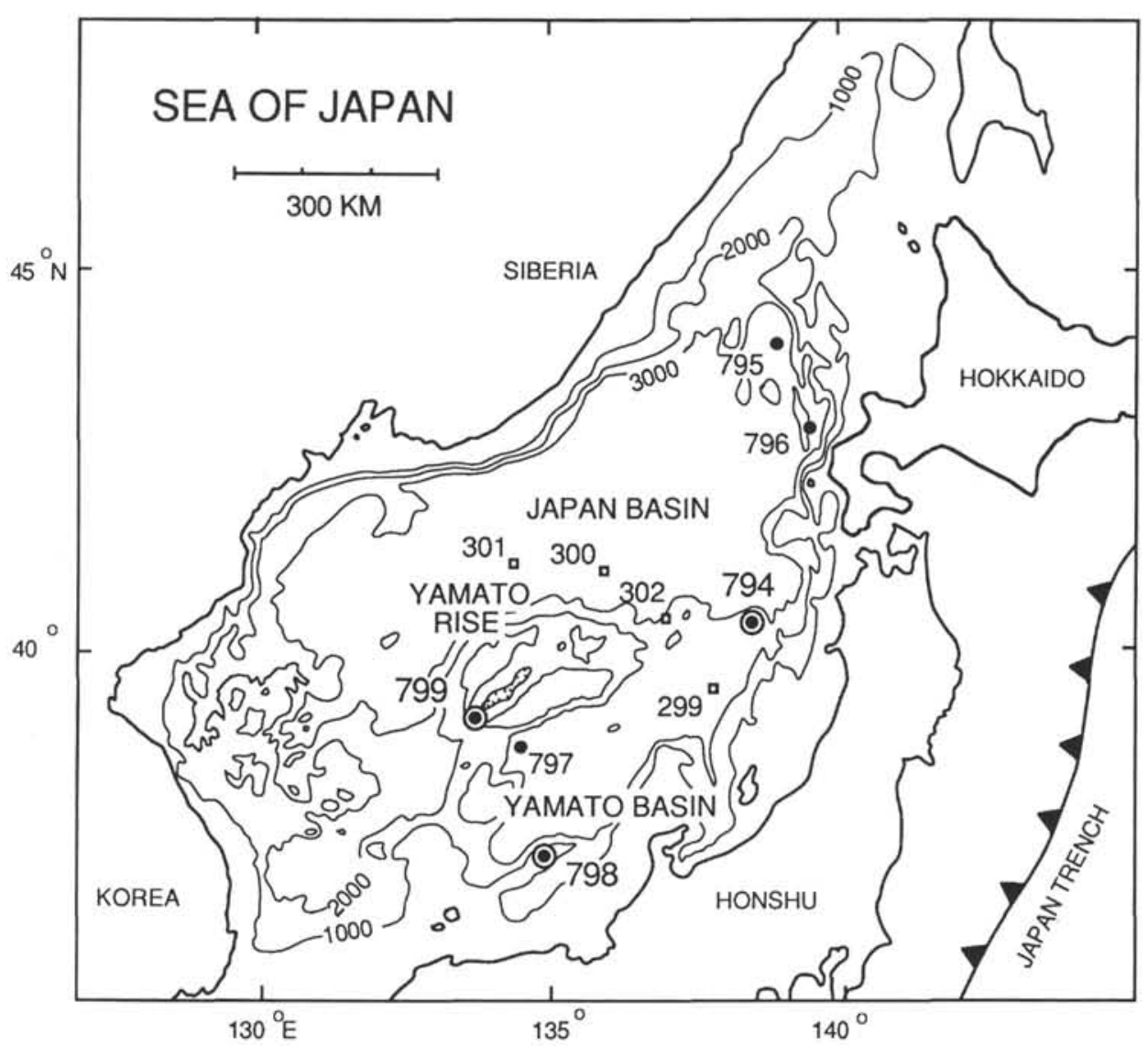

Figure 1. Location map of DSDP Leg 31 Sites 299-302, ODP Leg 127 Sites 794-797, and Leg 128 Sites 798 and 799.

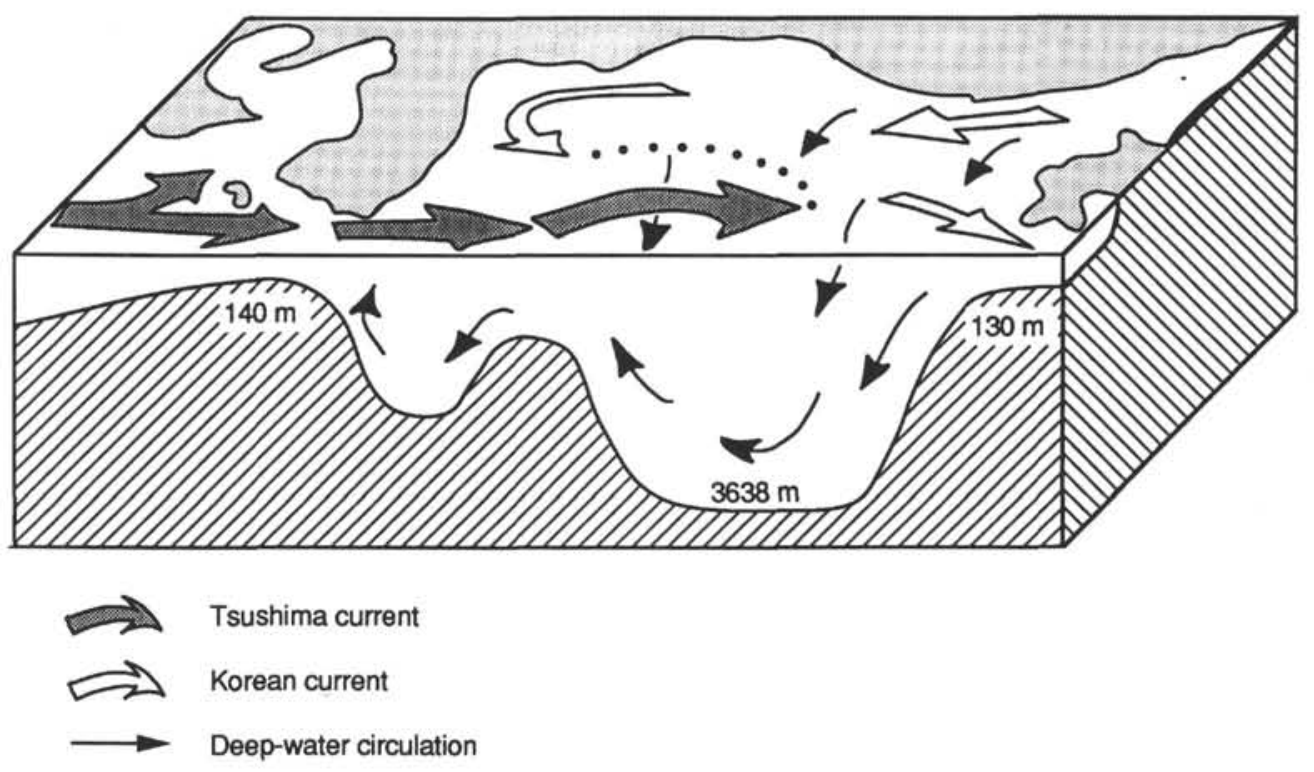

Figure 2. Scheme of modern surface- and deep-water circulation in the Sea of Japan (from Ingle, Suyehiro, von Breymann, et al., 1990; after Ingle, 1975; Matoba, 1984). 
von Breymann, et al., 1990). Based on shipboard paleomagnetic and microfossil data (Ingle, Suyehiro, von Breymann, et al., 1990), the average sedimentation rate of the entire sequence at Site 798 is about $12 \mathrm{~cm} / \mathrm{k} . \mathrm{y}$.

Site $799\left(39.22^{\circ} \mathrm{N}, 133.87^{\circ} \mathrm{E}\right.$; water depth, $\left.2073 \mathrm{~m}\right)$ was drilled in the Kita-Yamato Trough, a narrow sediment-filled graben within the much larger Yamato Rise in the South-Central Japan Sea (Fig. 1). The total depth of penetration was $1147.1 \mathrm{~m}$ below seafloor (mbsf). Sediments are of early Miocene to Holocene age and consist predominantly of diatomaceous ooze/clay, silty clay, clay, siliceous claystone, and porcellanite with common turbidites and slumps and authigenic carbonate (Ingle, Suyehiro, von Breymann, et al., 1990). Ash layers occur throughout the entire sediment sequence, with the maximum occurrence in the upper $100 \mathrm{~m}$. The middle and upper Miocene deposits in the Kita-Yamato Trough are dominated by laminated, organic-matter-rich siliceous claystones with authigenic dolomites. Diagenetic opal-A/opal-CT/authigenic quartz boundaries are well defined in this interval (Ingle, Suyehiro, von Breymann, et al., 1990). In the upper $468 \mathrm{~m}$ (i.e., last about $6.5 \mathrm{Ma}$ ) at Site 799, the sedimentation rate varies between about 2 and $13 \mathrm{~cm} / \mathrm{k}$.y. with an average of approximately $7 \mathrm{~cm} / \mathrm{k} . y$., as based on shipboard paleomagnetic data (Ingle, Suyehiro, von Breymann, et al., 1990). For the lower part of the sequence of Site 799 (i.e., Hole 799B), no sedimentation rates were calculated because only weak stratigraphic data were available.

\section{METHODS}

Organic carbon and total nitrogen were determined using a Heraeus $\mathrm{CHN}$ analyzer. Rock-Eval pyrolysis was performed according to the method described by Espitalié et al. (1977). Microscopy analysis of kerogen using polished, epoxy-impregnated blocks of undisturbed sediment made it possible to look at small-scale variations $(<<1 \mathrm{~mm})$. The macerals were classified according to the nomenclature described by Stach et al. (1982) and Hutton et al. (1980).

Mass accumulation rates of total organic carbon were calculated according to van Andel et al. (1975) using physical-property data from Ingle, Suyehiro, von Breymann et al. (1990), as follows:

$$
\text { MARTOC }=(T O C / 100) L S R(W B D-1.026(P O / 100)),
$$

where $M A R T O C=$ mass accumulation rate of total organic carbon $\left(\mathrm{g} / \mathrm{cm}^{2} / \mathrm{k} . \mathrm{y}.\right)$, TOC $=$ total organic carbon $(\mathrm{wt} \%), L S R=$ linear sedimentation rate $(\mathrm{cm} / \mathrm{k} . \mathrm{y}),. W B D=$ wet-bulk density $\left(\mathrm{g} / \mathrm{cm}^{3}\right)$, and $P O=$ porosity (\%).

Surface-water productivity was estimated with the following equations:

$$
P P=5.31(C(W B D-1.026(P O / 100)))^{0.71} L S R^{0.07} D E P^{0.45},
$$

where $P P=$ paleoproductivity $\left(\mathrm{g} \mathrm{C} / \mathrm{m}^{2} / \mathrm{yr}\right), C=$ (marine) organic carbon $(\mathrm{wt} \%), W B D=$ wet-bulk density $\left(\mathrm{g} / \mathrm{cm}^{3}\right), P O=$ porosity $(\%)$, $L S R=$ linear sedimentation rate $(\mathrm{cm} / \mathrm{k} . \mathrm{y}$.$) , and D E P=$ paleo-water depth of the seafloor (m). This formula is based on the relationship among the organic carbon accumulation rate in surface sediments, sedimentation rate, water depth, and measured (recent) surface-water productivity in oxic environments (Stein, 1986, based on Müller and Suess, 1979; Betzer et al., 1984). This means that equation (2) cannot be used to estimate productivity in anoxic environments such as those typical for the modern Black Sea and which may have occurred in the past in the Sea of Japan. For anoxic environments, Bralower and Thierstein (1984) suggested that at least $2 \%$ of the primary organic carbon is preserved in the sediments, based on a comparison of the accumulation rate of (marine) organic carbon and primary productivity in recent anoxic environments. They derived the following equation for estimating paleoproductivity in anoxic environments:

$$
P P=5 C(L S R(W B D-1.026(P O D / 100)))
$$

For discussion of these productivity equations and limits of application, see Stein $(1986,1991)$.

\section{RESULTS \\ Quantity of Organic Carbon}

The entire sequence of Pliocene to Quaternary sediments from Site 798 is characterized by high TOC values that are distinctly higher than those recorded in normal open-marine environments. Most of the values range between about $1 \%$ and $5 \%$ (Fig. 3 and Appendix). Maximum values of $3 \%$ to $5 \%$ are concentrated in the intervals between 80 and $120 \mathrm{mbsf}$ and below $500 \mathrm{mbsf}$. High-amplitude variations in organic carbon contents are typical of the upper $140 \mathrm{~m}$ of the sediment sequence at Site 798.

At Site 799, organic carbon values are also high and vary between $0.5 \%$ and $6 \%$ in the Miocene to Quaternary sediment sequence (Fig. 4; data listed in Ingle, Suyehiro, von Breymann, et al., 1990). Maximum organic carbon values of $3 \%$ to $6 \%$ are concentrated in the upper middle to upper Miocene, whereas in the Pliocene-Pleistocene interval lower values of $0.5 \%$ to $1.8 \%$ are typical. However, single organic carbon spikes of $3 \%$ to $5 \%$ also occur during the latter interval (Fig. 4).

To interpret the organic carbon data in terms of changes in flux, percentage values were transformed into accumulation rates. Accumulation rates have not been calculated for Site 799 because of the significant occurrence of turbidites and slumps (Ingle, Suyehiro, von Breymann, et al., 1990). At Site 798, accumulation rates of organic carbon vary generally between 0.05 and $0.5 \mathrm{~g} \mathrm{C} / \mathrm{cm}^{2} / \mathrm{k}$.y. (Fig. 5; Stein, 1991). The record can be divided into three intervals; the lowermost Pliocene (about 4.6 to $5 \mathrm{Ma}$ ) and upper Pliocene/Pleistocene (i.e., the last 2.4 Ma) intervals are characterized by high-amplitude variations between 0.1 and $0.6 \mathrm{~g}$ $\mathrm{C} / \mathrm{cm}^{2} / \mathrm{k}$.y., whereas the inter- calated interval ( 2.4 to $\left.4.6 \mathrm{Ma}\right)$ displays reduced accumulation rates of about 0.05 to $0.15 \mathrm{~g} \mathrm{C} / \mathrm{cm}^{2} / \mathrm{k}$.y.

\section{Composition of Organic Matter}

Data on organic carbon composition presented here are results mainly from elemental analyses (carbon/nitrogen ratios), Rock-Eval pyrolysis (hydrogen and oxygen index values), and kerogen microscopy data (for gas chromatography (GC) and gas chromatography/ mass spectrometry (GC/MS) data see Lichtfouse et al., this volume).

At Site 798, most of the $\mathrm{C} / \mathrm{N}$ ratios vary between 5 and 12 (Fig. 3), suggesting a mixed marine/terrigenous type of organic matter with the marine proportion dominant. In several samples from the lower Pleistocene and mid-Pliocene intervals, the high nitrogen contents of $0.3 \%$ to $0.5 \%$ and organic carbon contents of $0.5 \%$ to $2.5 \%$ result in very low $\mathrm{C} / \mathrm{N}$ ratios of 2 to 5 (Fig. 3). The occurrence of these values as single spikes throughout the two intervals suggests a different primary composition for the organic matter (or an increased content of inorganic nitrogen) rather than diagenetic alteration. Near the bottom of Site 798 (i.e., in the lower Pliocene), maxima in organic carbon contents coincide with increased $\mathrm{C} / \mathrm{N}$ ratios of about 15 (Fig. 3) that may indicate some higher amounts of terrigenous organic carbon.

Hydrogen index values vary between 100 and $600 \mathrm{mg} \mathrm{HC} / \mathrm{g} \mathrm{C}_{\text {org }}$ in the sediments from Site 798 (Figs. 3 and 6A), which supports the $\mathrm{C} / \mathrm{N}$ data and indicates a mixture between marine and terrigenous organic carbon, with the marine proportion dominant in most of the samples. The unusually high oxygen index values measured on samples from Hole 798A may result from significant amounts of labile organic matter (e.g., sugars, proteins) still present in the immature sediments of the upper about $100 \mathrm{~m}$ of the sequence (cf. Stein, Littke, et al., 1989). In carbonaterich samples, $\mathrm{CO}_{2}$ generated from carbonate during pyrolysis may have also caused increased oxygen indices. 

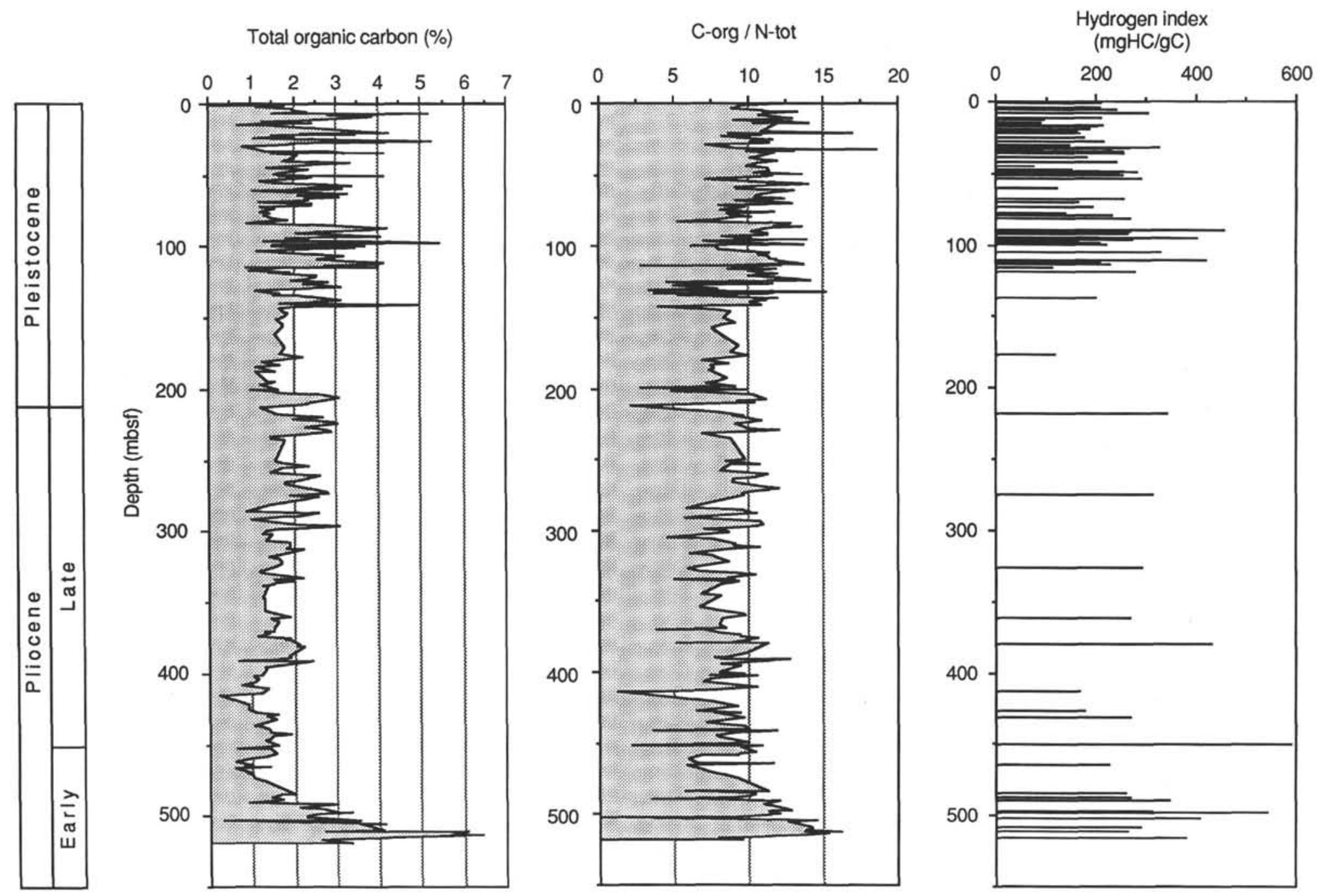

Figure 3. Total organic carbon, and carbon/nitrogen ratio, and hydrogen index values vs. depth at Site 798. 


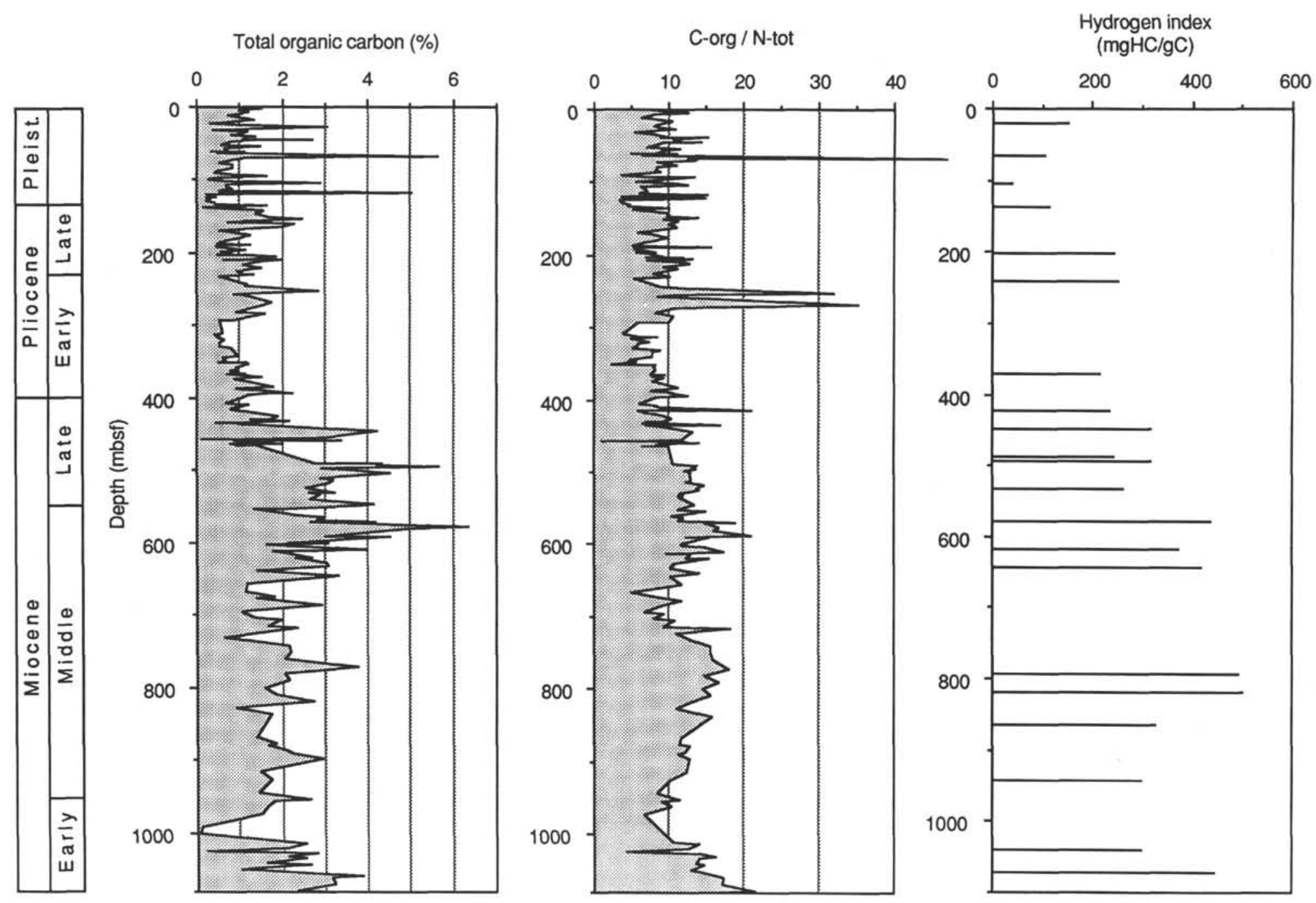



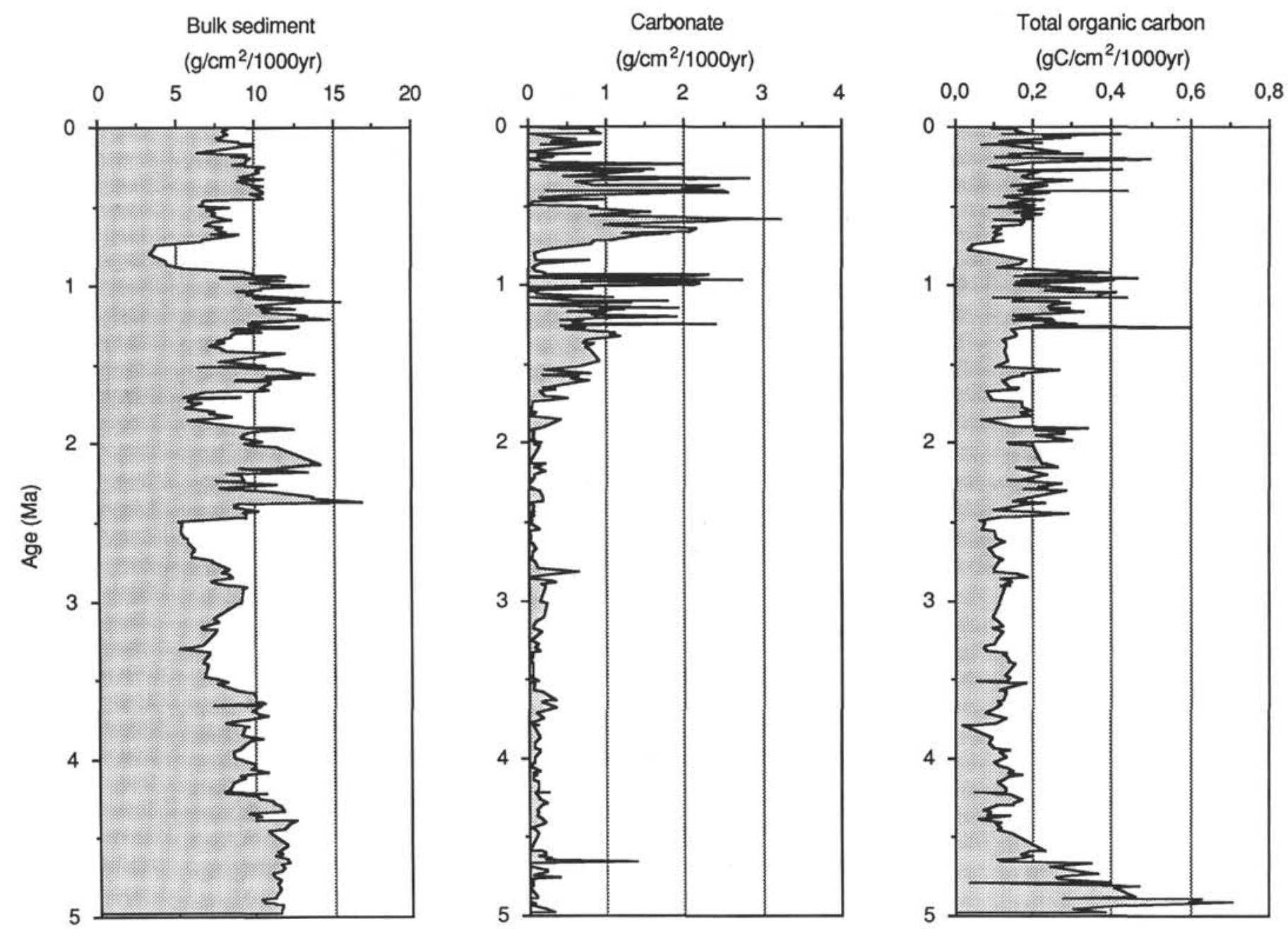

Figure 5. Accumulation rate of the bulk-sediment fraction, carbonate, and TOC vs. age at Site 798. 
A

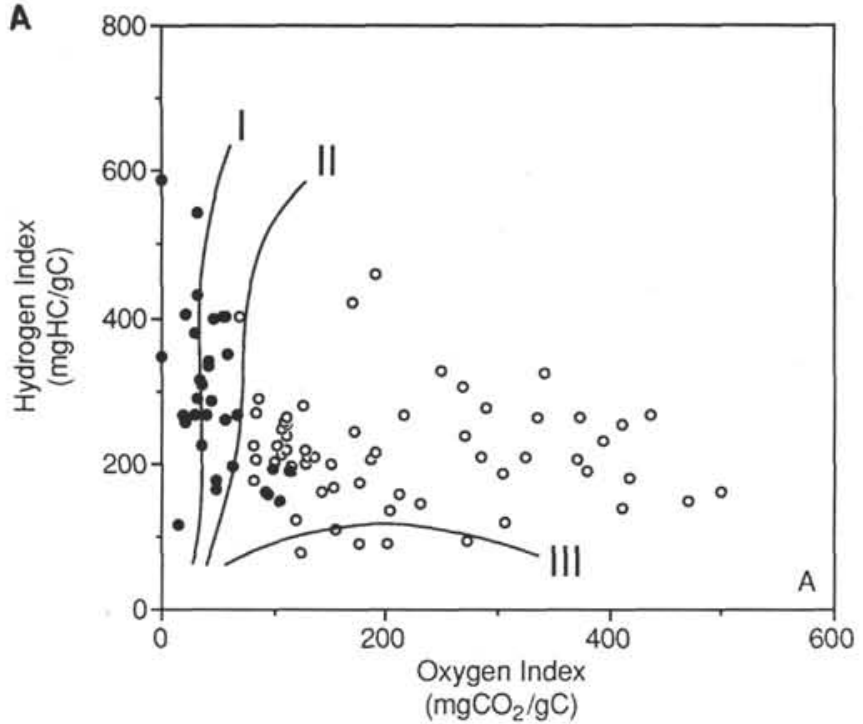

B

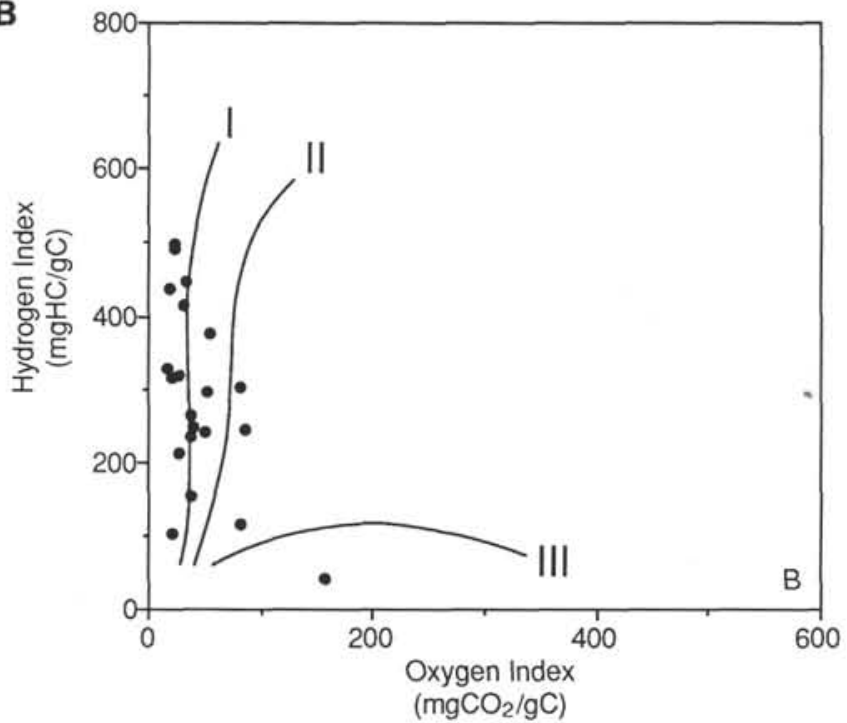

Figure 6. Results from Rock-Eval pyrolysis: hydrogen index vs. oxygen index. A. Site 798 (open symbols, Hole 798A; solid symbols, Hole 798B). B. Site 799.

The first results of kerogen microscopy performed on selected sediment samples from Hole 798A also support the predominance of marine organic matter. The dominant maceral is alginite; well-preserved, yellow to yellowish green fluorescing bodies of Tasmanales-type algae and yellowish orange to yellow fluorescing laminae (lamalginite) are typical.

At Site 799 most of the $\mathrm{C} / \mathrm{N}$ ratios vary between 5 and 20 , with some single spikes of up to 30 (Fig. 4). In the Pliocene-Pleistocene interval, $\mathrm{C} / \mathrm{N}$ ratios of about 10 are dominant, whereas in the Miocene interval higher $\mathrm{C} / \mathrm{N}$ ratios of about 15 are typical, suggesting that significant amounts of terrigenous organic carbon were deposited during the latter time interval. In general, however, marine organic carbon seems to be the major carbon fraction at Site 799, too. Results of Rock-Eval pyrolysis display hydrogen and oxygen index values similar to those recorded for Hole 798B (Fig. 6B). Hydrogen index values are relatively high; most of the values vary between 200 and $500 \mathrm{mg} \mathrm{HC} / \mathrm{g} \mathrm{C}$, supporting the dominance of marine organic matter, especially in the Miocene interval (Fig. 4). Lower hydrogen index values of 50 to $150 \mathrm{mg} \mathrm{HC} / \mathrm{g} \mathrm{C}$ measured in a few samples indicate that significant amounts of terrigenous organic carbon may also occur. More analyses are necessary before a more detailed interpretation of the changes in organic carbon composition throughout the entire sediment sequence is possible.

By comparing the Rock-Eval data from Sites 798 and 799 with a diagram of the correlation between hydrogen index values and maceral composition based on data from the Deep Sea Drilling Project (DSDP) (Stein et al., 1986), rough estimates of marine organic carbon are possible; the values vary between about $20 \%$ and $80 \%$, with the values dominantly between $50 \%$ and $80 \%$.

\section{Maturity of Organic Matter}

Based on the hydrogen and oxygen index values (i.e., the position of the data points in van Krevelen-type diagrams; Figs. 6A and 6B) and the low temperatures of maximum pyrolysis yield $\left(\mathrm{T}_{\max }\right.$ values of $378^{\circ}$ to $428^{\circ} \mathrm{C}$; Stein, 1991), the organic carbon deposited at Sites 798 and 799 is still immature.

\section{DISCUSSION}

According to the $\mathrm{C} / \mathrm{N}$ ratios, hydrogen indices, and initial maceral data (see the preceding), the organic carbon fraction at Sites 798 and 799 is characterized by high amounts of marine organic material. The accumulation of major amounts of marine organic carbon requires special environmental conditions such as increased surface-water productivity, increased preservation rate of organic matter under anoxic conditions, and/or rapid burial of organic matter by turbidites, which also enhances the preservation of organic carbon (e.g., Demaison and Moore, 1980; Tissot et al., 1980; Stein, 1991).

Because high organic carbon values were recorded throughout the entire sediment sequences at Sites 798 and 799 , rapid burial by turbidites that might have occurred occasionally at Site 798 and certainly more often at Site 799 (Ingle, Suyehiro, von Breymann, et al., 1990) cannot be regarded as the dominant mechanism controlling the general enrichment in organic carbon. Increased preservation in turbidites may explain only single events or short-lived intervals of organic carbon enrichment. For example, the lower Pliocene sediments recovered at Site 798 that are characterized by an increased terrigenous organic carbon content and maximum accumulation rates (Figs. 3 and 5) are also rich in siliciclastic coarse-grained detritus including glauconite and quartz turbiditic sands (Ingle, Suyehiro, von Breymann, et al., 1990). In this case, organic carbon enrichment may have been caused by rapid burial (and thus an increased preservation rate) of the organic matter in the turbidites (which implies that the uplift of Oki Ridge occurred after that time, i.e., during the late Pliocene/Pleistocene; Ingle, Suyehiro, von Breymann, et al., 1990). In general, however, high surface-water productivity and/or an increased preservation rate under anoxic conditions should have caused mainly (marine) organic carbon accumulation at Site 799 and, especially, at Site 798. Furthermore, the long-term changes in organic carbon deposition are certainly influenced by the tectonic evolution of the Japan Sea.

Suggesting that about $50 \%$ to $80 \%$ of the organic carbon is of marine origin (see the preceding) implies that the accumulation rate of marine organic carbon at Site 798 varies between about 0.05 and $0.4 \mathrm{~g} \mathrm{C} / \mathrm{cm}^{2} / \mathrm{k}$.y.; these values are similar to those recorded in the high-productivity upwelling area off Northwest Africa (Stein, ten Haven, et al., 1989; Stein, 1991). Although accumulation rates have not been calculated for Site 799 because of the occurrence of turbidites and slumps and a still highly preliminary stratigraphy (Ingle, Suyehiro, von Breymann, et al., 1990), the average sedimentation rates (and thus also accumulation rates of marine organic carbon) are definitely also high at this site.

According to smear slide analyses and X-ray-diffraction (XRD) measurements, the sediments at Sites 798 and 799 contain high amounts of diatoms and sponge spicules (opal-A), opal-CT, or authi- 


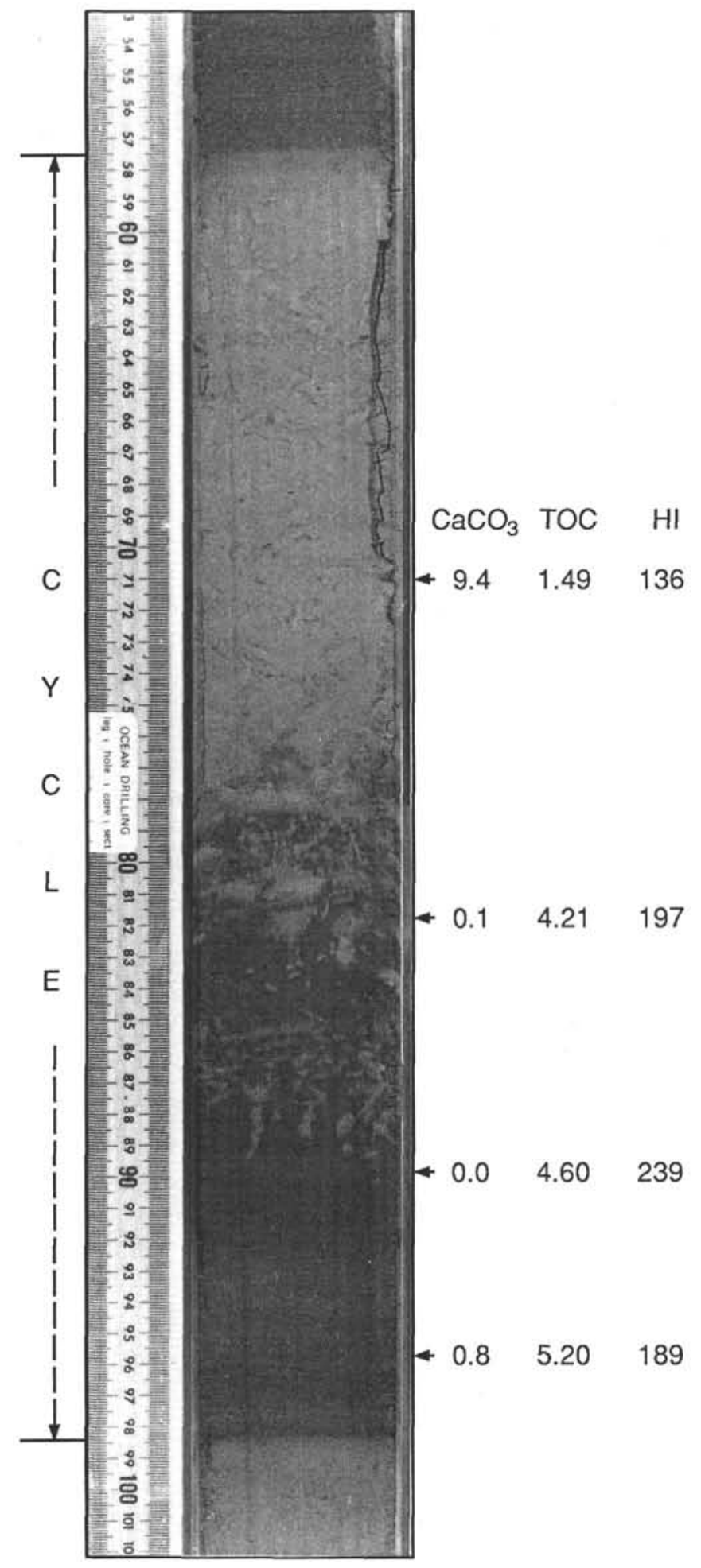

Figure 7. Dark/light cycle in Section 128-798A-1H-4, $57.5-98.5 \mathrm{~cm}$. Selected carbonate and total organic carbon contents (wt\%) and hydrogen index values (mg HC/g C) are shown. genic quartz; the major lithologies are diatomaceous ooze/clay, siliceous claystone, and porcellanite (Ingle, Suyehiro, von Breymann, et al., 1990). These types of sediment also indicate an environment of high-surface-water productivity (e.g., Isaacs et al., 1983; Berger et al., 1989; Bohrmann and Stein, 1989). Based on smear slide and $\mathrm{X}$-ray-fluorescence data from the Site 798 sediments, the accumulation rates of opal were estimated semiquantitatively to reach maximum values of 3 to $8 \mathrm{~g} / \mathrm{cm}^{2} / \mathrm{k}$.y. at approximately 2.2 to $2.5 \mathrm{Ma}$ (Ingle, Suyehiro, von Breymann, et al., 1990). These rates are similar to those determined for the modern high-productivity upwelling environment off Peru (Scheidegger and Krissek, 1983).

At Site 798, the distinct increase in the accumulation rates of (marine) organic carbon and biogenic opal content near $2.4 \mathrm{Ma}$ (Fig. 5; Stein, 1991) is interpreted as the result of an increase in surface-water productivity. This increase in productivity is paralleled by a climate-controlled increase in eolian quartz supply (Dersch and Stein, this volume), both of which were triggered by the development of major Northern Hemisphere glaciation (e.g., Shackleton et al., 1984), which has probably resulted in intensified atmospheric and oceanic circulation (causing increased nutrient supply to the ocean surface) and aridification in Asia. Similar changes have also been recorded in other parts of the global ocean, such as the tropical/subtropical Atlantic (e.g., Stein, 1985a, 1985b; Ruddiman and Janecek, 1989).

To estimate the surface-water paleoproductivity more quantitatively, equation (2) (see "Methods" section) was used. The calculated values vary between about 110 and $260 \mathrm{~g} \mathrm{C} / \mathrm{m}^{2} / \mathrm{yr}$ at the Site 798 position (Table 1). These values are similar to those calculated for sediments from the upwelling area off Northwest Africa (Müller et al., 1983; Sarnthein et al., 1987; Stein, 1991). The Japan Sea values, however, should be used with caution because equation (2) is based on data derived from open-ocean (sub-) oxic environments (cf. Stein, 1986). If anoxic conditions are assumed, distinct (marine) organic carbon enrichments of $4 \%$ can be reached even though productivity remains relatively low $\left(150 \mathrm{~g} \mathrm{C} / \mathrm{m}^{2} / \mathrm{yr}\right.$, using equation (3); Table 1). Based on the relationship between organic carbon content and (pyritic) sulfur (Leventhal, 1983; Berner, 1984, 1989), these anoxic deepwater conditions should have occurred at least occasionally in the Japan Sea during Miocene to Quaternary times (Ingle, Suyehiro, von Breymann, et al., 1990; Stein, 1991). This interpretation is in agreement with results from DSDP Leg 31 and piston-core data (Ujiie and Ichikura, 1973; Ingle, 1975; Oba, 1983; Oba et al., 1991).

A key to deciphering the factors causing the organic carbon enrichments at Site 798 (i.e., high productivity vs. high preservation vs. high terrigenous input) might lie in a detailed investigation of the remarkable dark/light cycles preserved in the Quaternary sediments at this site (Fig. 7; Ingle, Suyehiro, von Breymann, et al., 1990). In general, the dark intervals are finely laminated and characterized by increased organic carbon contents of up to $6 \%$, whereas the lighter intervals are homogeneous or bioturbated and display organic carbon contents of about $2 \%$. The thickness of these cycles varies between 10 and $100 \mathrm{~cm}$, which corresponds to periods of about 1000 to 12,000 $\mathrm{yr}$ (based on mean sedimentation rates). This means these cycles have periods distinctly lower than those of the Milankovitch-type cycles.

Several of the dark/light cycles have been investigated in more detail for their organic carbon and carbonate contents as well as hydrogen and oxygen indices (Table 2). Detailed kerogen microscopy study on these cycles is in progress (R. Stax, unpubl. data). Although marine organic matter is probably the major fraction of the organic matter in most of the samples investigated, varying hydrogen index 
Table 1. Mean productivity values for Quaternary light, bioturbated/homogeneous $\left(1 \%-2 \% \mathrm{C}_{\mathrm{org}}\right)$ and dark, laminated sediments (3\%-4\% $\left.\mathrm{C}_{\mathrm{org}}\right)$.

\begin{tabular}{|c|c|c|c|c|c|}
\hline \multirow{2}{*}{$\begin{array}{c}\text { Marine } C_{\text {org }} \\
(\%)\end{array}$} & \multirow{2}{*}{$\begin{array}{c}\text { Linear } \\
\text { sedimentation } \\
\text { rate } \\
(\mathrm{cm} / \mathrm{k} . \mathrm{y} .)\end{array}$} & \multirow{2}{*}{$\begin{array}{l}\text { Wet-bulk } \\
\text { density } \\
\left(\mathrm{g} / \mathrm{cm}^{3}\right)\end{array}$} & \multirow{2}{*}{$\begin{array}{c}\text { Porosity } \\
\text { (\%) }\end{array}$} & \multicolumn{2}{|c|}{ Productivity ( $\mathrm{g} \mathrm{C} / \mathrm{m}^{2} / \mathrm{k} . \mathrm{y}$ ) } \\
\hline & & & & Equation (2) & Equation (3) \\
\hline $1-2$ & 12 & 1.5 & 70 & $110-180$ & \\
\hline \multirow[t]{2}{*}{$3-4$} & 12 & 1.4 & 74 & $215-260$ & \\
\hline & & & & & $120-150$ \\
\hline
\end{tabular}

values of 100 to $400 \mathrm{mg} \mathrm{HC} / \mathrm{g} \mathrm{C}$ indicate that the composition of the organic matter changes throughout a cycle (Fig. 8 and Table 2). In general, hydrogen values are higher in the darker, more organiccarbon-rich part of the cycles than in the lighter part, suggesting increased preservation (or production) of marine organic matter in the dark intervals. The higher oxygen index values typical of the light intervals (Fig. 8) may also point to stronger oxidation/degradation of the organic matter (cf. Herbin et al., 1982). The $\mathrm{C} / \mathrm{N}$ ratios (Table 2) do not display any distinct difference between the lithologies. GC and GC/MS data produced from a few samples selected from the light and dark intervals are also highly similar (Lichtfouse et al., this volume).
For one cycle (Section 128-798B-10H-7), some detailed data are available, including carbonate, organic carbon, and biogenic opal contents and hydrogen and oxygen indices (Figs. 8 and 9) as well as XRD data (Stein, 1991; Dersch and Stein, this volume). Based on these results, a possible interpretation of the organic carbon enrichment for this specific cycle is as follows.

In the lower part of the cycle, the dark, laminated sediments are characterized by increasing contents of carbonate and biogenic opal and a high marine organic carbon content (Fig. 9), which may suggest increased productivity and increased organic carbon flux. If the oxygen demand for the oxidation of organic matter exceeds the

Table 2. Oxygen isotope data, carbonate, TOC and total nitrogen contents, $\mathrm{C} / \mathrm{N}$ ratio, and hydrogen and oxygen index values of sediment samples from dark/light cycles.

\begin{tabular}{|c|c|c|c|c|c|c|c|c|c|}
\hline $\begin{array}{l}\text { Core, section } \\
\text { interval }(\mathrm{cm})\end{array}$ & $\begin{array}{l}\text { Depth } \\
\text { (mbsf) }\end{array}$ & $\begin{array}{l}\text { Age } \\
\text { (Ma) }\end{array}$ & $\begin{array}{c}\delta^{18} \mathrm{O} \\
(\% / \mathrm{PDB})\end{array}$ & $\begin{array}{c}\mathrm{CaCO}_{3} \\
(\%)\end{array}$ & $\begin{array}{l}\text { TOC } \\
(\%)\end{array}$ & $\underset{(\%)}{N}$ & $\mathrm{C}_{\text {org }} / \mathrm{N}$ & $\begin{array}{c}\mathrm{HI} \\
(\mathrm{mg} \mathrm{HC} / \mathrm{g} \mathrm{C})\end{array}$ & $\begin{array}{c}\mathrm{OI} \\
(\mathrm{mg} \mathrm{CO} / \mathrm{g} \mathrm{C})\end{array}$ \\
\hline \multicolumn{10}{|l|}{$128-798 \mathrm{~A}-$} \\
\hline $1 \mathrm{H}-4,71-73$ & 5.21 & 0.04 & & 9.5 & 1.49 & 0.13 & 11.5 & 136 & 203 \\
\hline $1 \mathrm{H}-4,82-84$ & 5.32 & 0.04 & & 0.1 & 4.20 & 0.32 & 13.1 & 197 & 115 \\
\hline $1 \mathrm{H}-4,90-92$ & 5.40 & 0.05 & & 0.1 & 4.60 & 0.42 & 11.0 & 239 & 111 \\
\hline $1 \mathrm{H}-4,96-98$ & 5.46 & 0.05 & & 0.9 & 5.19 & 0.39 & 13.3 & 189 & 115 \\
\hline $2 \mathrm{H}-3,123-125$ & 13.53 & 0.11 & & 1.7 & 0.70 & 0.05 & 14.0 & 90 & 177 \\
\hline $2 \mathrm{H}-3,146-148$ & 13.76 & 0.12 & & 7.4 & 1.13 & 0.11 & 10.3 & 90 & 201 \\
\hline $3 \mathrm{H}-2,19-21$ & 19.99 & 0.17 & & 4,3 & 2.18 & 0.20 & 10.9 & 161 & 142 \\
\hline $3 \mathrm{H}-2,31-33$ & 20.11 & 0.17 & & 8.7 & 2.89 & 0.17 & 17.0 & 198 & 152 \\
\hline $3 \mathrm{H}-2,43-45$ & 20.23 & 0.17 & & 5.6 & 3.46 & 0.31 & 11.2 & 210 & 136 \\
\hline $3 \mathrm{H}-2,47-49$ & 20.27 & 0.17 & & 3.1 & 1.68 & 0.15 & 11.2 & 166 & 154 \\
\hline $4 \mathrm{H}-4,47-49$ & 32.27 & 0.27 & & 15.7 & 1.35 & 0.10 & 13.5 & 145 & 231 \\
\hline $4 \mathrm{H}-4,76-78$ & 32.56 & 0.27 & & 0.0 & 2.78 & 0.15 & 18.5 & 248 & 108 \\
\hline $4 \mathrm{H}-4,84-86$ & 32.64 & 0.27 & & 0.3 & 3.21 & 0.26 & 12.3 & 256 & 110 \\
\hline $4 \mathrm{H}-4,94-96$ & 32.74 & 0.27 & & 0.0 & 4.16 & 0.32 & 13.0 & 265 & 112 \\
\hline $6 \mathrm{H}-3,7-9$ & 49.12 & 0.41 & 4.08 & 14.2 & 2.43 & 0.19 & 12.8 & 244 & 171 \\
\hline $6 \mathrm{H}-3,18-20$ & 49.23 & 0.41 & 3.87 & 7.5 & 2.98 & 0.22 & 13.5 & 281 & 126 \\
\hline $6 \mathrm{H}-3,28-30$ & 49.32 & 0.41 & & 2.2 & 4.16 & 0.37 & 11.2 & 254 & 112 \\
\hline $6 \mathrm{H}-3,35-37$ & 49.39 & 0.41 & 4.12 & 23.6 & 1.67 & 0.15 & 11.1 & 216 & 190 \\
\hline $6 \mathrm{H}-3,46-48$ & 49.50 & 0.41 & & 24.4 & 1.77 & 0.16 & 11.1 & 206 & 186 \\
\hline $11 \mathrm{H}-3,94-96$ & 97.85 & 0.97 & & 16.4 & 1.50 & 0.16 & 9.4 & 159 & 211 \\
\hline $11 \mathrm{H}-3,146-148$ & 98.34 & 0.97 & & 20.1 & 3.70 & 0.27 & 13.7 & 218 & 128 \\
\hline $11 \mathrm{H}-4,2-4$ & 98.40 & 0.97 & & 20.1 & 3.51 & 0.27 & 13.0 & 209 & 130 \\
\hline $12 \mathrm{H}-8,0-5$ & 112.85 & 1.07 & 3.33 & 2.0 & 3.26 & 0.29 & 11.2 & 225 & 102 \\
\hline $12 \mathrm{H}-8,23-25$ & 113.05 & 1.08 & 4.64 & 1.8 & 1.48 & 0.18 & 8.2 & 121 & 119 \\
\hline $12 \mathrm{H}-8,52-54$ & 113.30 & 1.08 & & 0.0 & 1.99 & 0.22 & 9.0 & 177 & 81 \\
\hline $12 \mathrm{H}-8,62-64$ & 113.39 & 1.08 & & 0.0 & 3.80 & 0.32 & 11.9 & 205 & 83 \\
\hline $12 \mathrm{H}-8,70-72$ & 113.46 & 1.08 & & 0.0 & 4.00 & 0.33 & 12.1 & 226 & 81 \\
\hline $12 \mathrm{H}-8,75-77$ & 113.50 & 1.08 & 4.34 & 0.0 & 2.21 & 0.20 & 11.1 & 161 & 92 \\
\hline $15 \mathrm{H}-4,5-6$ & 136.58 & 1.24 & & 6.2 & 3.12 & 0.26 & 12.0 & 199 & 128 \\
\hline $15 \mathrm{H}-4,14-16$ & 136.68 & 1.25 & & 1.5 & 3.97 & 0.25 & 15.9 & 220 & 112 \\
\hline \multicolumn{10}{|l|}{ 128-798B- } \\
\hline $10 \mathrm{H}-7,25-27$ & 93.23 & 0.96 & & 4.2 & 2.32 & 0.24 & 9.7 & 196 & 62 \\
\hline $10 \mathrm{H}-7,54-56$ & 93.51 & 0.96 & & 0.7 & 4.67 & 0.36 & 13.0 & 403 & 54 \\
\hline $10 \mathrm{H}-7,74-75$ & 93.70 & 0.96 & & 8.1 & 4.61 & 0.36 & 12.8 & 333 & 42 \\
\hline $10 \mathrm{H}-7,75-76$ & 93.71 & 0.96 & & 12.7 & 4.08 & 0.32 & 12.8 & 349 & 59 \\
\hline $10 \mathrm{H}-7,85-87$ & 93.80 & 0.97 & & 2.7 & 4.82 & 0.40 & 12.1 & 399 & 46 \\
\hline $10 \mathrm{H}-7,91-93$ & 93.86 & 0.97 & & 2.7 & 2.94 & 0.28 & 10.5 & 403 & 57 \\
\hline
\end{tabular}

Note: Sample age based on mean sedimentation rate. 


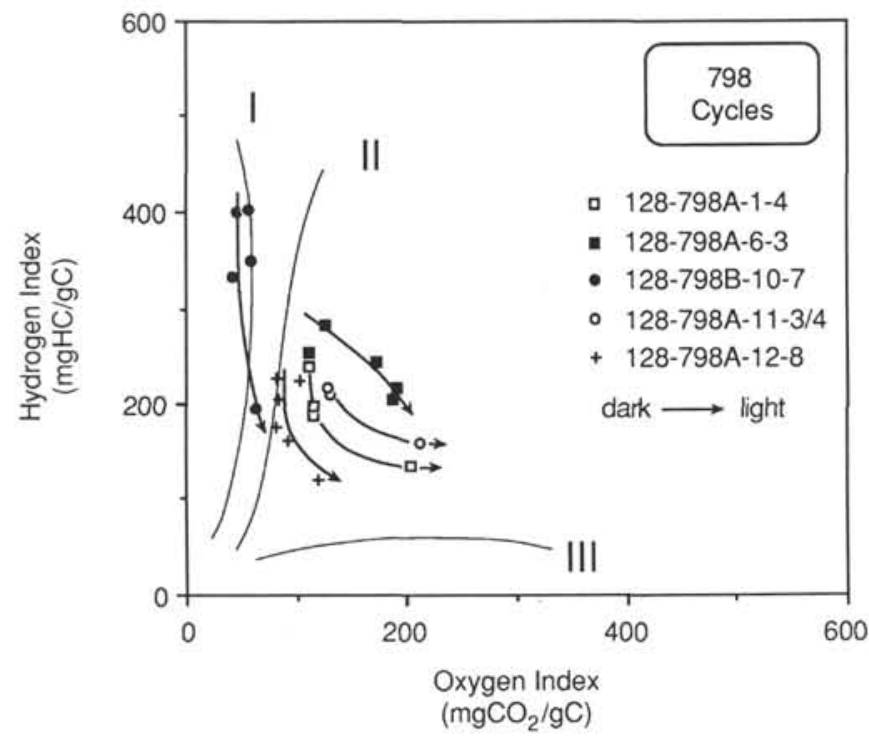

Figure 8 . Hydrogen index vs. oxygen index values shows higher hydrogen index values occur in the dark, organic-carbon-enriched interval and lower values in the light, relatively organic-carbon-poor interval of an individual dark/light cycle (cf. Table 1).

oxygen supply, anoxic conditions occur in the water column, which enhances the preservation of organic matter in the sediment. These conditions may have already developed before times of maximum productivity. In the middle part, carbonate content and (less distinctly) biogenic opal content decrease, whereas the marine organic carbon content remains high. This may reflect decreasing productivity, whereas the preservation rate of organic carbon remained high under anoxic deep-water conditions. These anoxic conditions may have occurred during times of lowered sea level when the Japan Sea was more restricted from the open Pacific Ocean and the oceanic circulation and ventilation of the deep-water sphere in the Japan Sea were distinctly reduced (cf. Oba, 1983; Oba et al., 1991).
In the upper light part of the cycle, the marine organic carbon content and hydrogen index values also decrease (Fig. 9 and Table 2), indicating the development of more oxidizing conditions in the Japan Sea during times of higher sea level, reestablishment of the connection to the Pacific Ocean, and intensification of oceanic circulation (cf. Oba, 1983; Oba et al., 1991).

For detailed paleoenvironmental reconstructions, stable oxygen isotope data (for correlation with global climate, i.e., glacial/interglacial or low/high sea-level conditions) as well as accumulation rates for the different variables calculated separately for glacial and interglacial intervals are absolutely necessary. Furthermore, results of shipboard as well as shore-based studies of the Leg 127 and 128 sediments (e.g., Ingle, Suyehiro, von Breymann, et al., 1990; Tamaki, Pisciotto, Allan, et al., 1990; Föllmi et al., this volume; Lichtfouse et al., this volume) indicate that these remarkable dark/light cycles are very different in lithologic detail, which suggests that different paleoenvironmental situations caused the various cycles. Thus, the explanation given previously for the cycle in Section 128-798B-10H-7 cannot be used as a general model. Information from a large number of cycles is required before a more precise reconstruction of the depositional environment is possible. It is hoped that this information will result from a planned multidisciplinary study of the dark/light cycles (K. Föllmi et al., unpubl. data; R. Stax, unpubl. data).

\section{CONCLUSIONS}

Results of organic geochemical and sedimentological investigations yielded information about the depositional and paleoceanographic evolution of the Japan Sea during Miocene to Quaternary times.

1. The sediments from Sites 798 and 799 are characterized by high amounts of organic carbon, ranging between $0.5 \%$ and $6 \%$. Accumulation rates of up to $0.4 \mathrm{~g} \mathrm{C} / \mathrm{cm}^{2} / \mathrm{k}$.y. were calculated for the Site 798 sediments. The organic matter is a mixture of marine and terrigenous organic compounds, with the marine proportion dominant in the majority of the sequences.

2. Dominant mechanisms controlling the (marine) organic carbon enrichment are probably high-surface-water productivity and increased preservation rates under anoxic deep-water conditions.

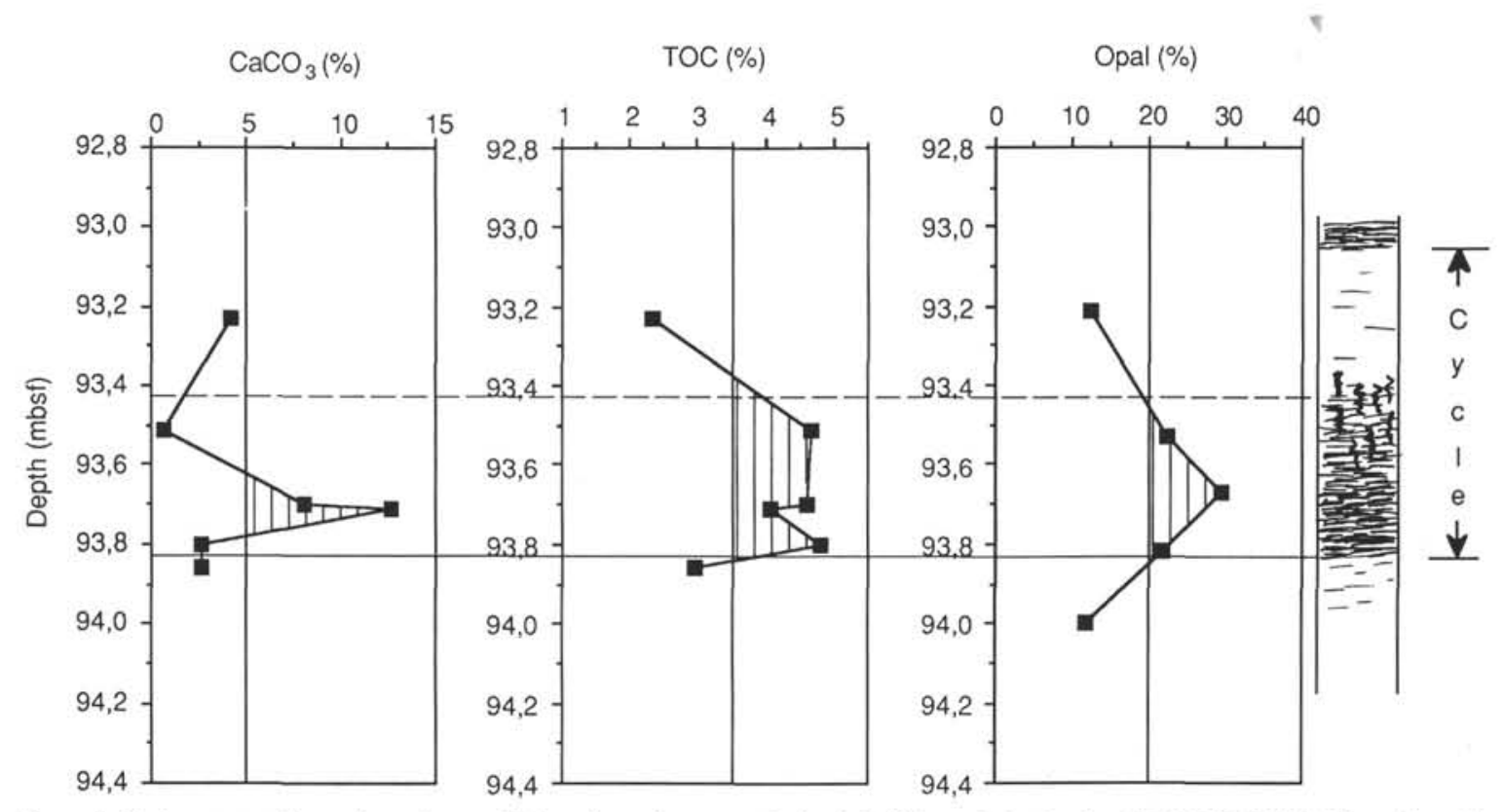

Figure 9. Carbonate, total organic carbon, and biogenic opal contents in the dark/light cycle in Section 128-798B-10H-7. Biogenic opal from R. Dunbar (unpubl. data). 
3. In the uppermost lower Pliocene sediments at Site 798 and the Quaternary to Miocene sediments at Site 799, rapid burial of organic carbon in turbidites may have occurred episodically.

4. Remarkable cycles of dark, laminated sediments with a maximum organic carbon content of more than 5\% and light, bioturbated or homogeneous sediments with lower organic carbon contents indicate dramatic short-term paleoceanographic variations, which were most highly developed during middle/late Pleistocene times. First comparison of the carbonate, opal, and organic carbon data suggests that a succession of anoxic and high-productivity conditions to anoxic and reduced-productivity conditions to oxic conditions caused some of the cycles at Site 798.

5 . More detailed records of the accumulation rates of marine and terrigenous organic carbon, carbonate, and biogenic opal and the correlation with oxygen stable isotopes (i.e., the correlation with glacial/interglacial and low/high-sea-level cycles) are necessary for a more precise and complete reconstruction of the environmental history of the Japan Sea.

\section{ACKNOWLEDGMENTS}

The performance of stable isotope measurements by M. Segl (Bremen University) and production of some of the Rock-Eval data by B. Horsfield (KFA Jülich) are gratefully acknowledged. We thank E. Biermanns, D. Brosinsky, M. Dersch, and U. Mann for technical assistance. We also thank Drs. K. Pisciotto, B.R.T. Simoneit, and K.F.M. Thompson for their numerous constructive suggestions for improvement of the manuscript. Financial support was provided by the Deutsche Forschungsgemeinschaft (Grant No. STE 412/3). This is contribution no. 446 of the Alfred-Wegener-Institute for Polar and Marine Research.

\section{REFERENCES}

Berger, W. H., Smetacek, V., and Wefer, G., 1989. Productivity of the Ocean: Past and Present. Life Sci. Res. Rep., 44.

Berner, R. A., 1984. Sedimentary pyrite formation: an update. Geochim. Cosmochim. Acta, 48:605-615.

1989. Biogeochemical cycles of carbon and sulfur and their effect on atmospheric oxygen over Phanerozoic time. Palaeogeogr., Palaeoclimatol., Palaeoecol., 75:97-122.

Betzer, P. R., Showers, W. J., Laws, E. A., Winn, C. D., Ditullo, G. R., and Kroopnick, P. M., 1984. Primary productivity and particle fluxes on a transect of the equator at $153^{\circ} \mathrm{W}$ in the Pacific Ocean. Deep-Sea Res. Part A, 31:1-11.

Bohrmann, G., and Stein, R., 1989. Biogenic silica at ODP Site 647 in the Southern Labrador Sea: occurrence, diagenesis, and paleoceanographic implications. In Srivastava, S. P., Arthur, M. A., Clement, B., et al., Proc. ODP, Sci. Results, 105: College Station, TX (Ocean Drilling Program), 155-170.

Bralower, T. J., and Thierstein, H. R., 1984. Low productivity and slow deepwater circulation in Mid-Cretaceous oceans. Geology, 12:614-618.

Demaison, G. J., and Moore, G. T., 1980. Anoxic environments and oil source bed genesis. Org. Geochem., 2:9-31.

Espitalié, J., Laporte, J. L., Madec, M., Marquis, F., Leplat, P., Paulet, J., and Boutefeu, A., 1977. Méthode rapide de characterisation des roches-mere, de leur potential petrolier et de leur degre d'évolution. Rev. Inst. Fr. Petrol. 32:23-42.

Hutton, A. C., Kantsler, A. J., Cook, A. C., and McKirdy, D. M., 1980. Organic matter in oil shales. APEA J., 20:44-67.

Ingle, J. C., Jr., 1975. Pleistocene and Pliocene foraminifera from the Japan Sea Leg 31, Deep Sea Drilling Project. In Karig, D. E., Ingle, J. C., Jr. et al., Init. Repts. DSDP, 31: Washington (U.S. Govt. Printing Office), 693-702.

Ingle, J. C., Jr., Suyehiro, K., von Breymann, M. T., et al., 1990. Proc. $O D P$, Init. Repts., 128: College Station, TX (Ocean Drilling Program).

Isaacs, C. M., Pisciotto, K. A., and Garrison, R. E., 1983. Facies and diagenesis of the Monterey Formation, California: a summary. In Ijima, A., Hein, J. R., and Siever, R. (Eds.), Siliceous Deposits in the Pacific Region. Developments in Sedimentology, 36:247-281.

Kobayashi, K., and Nomura, M., 1972. Iron sulfides in the core from Sea of Japan and their geophysical implications. Earth Planet. Sci. Lett., 16:200-208.

Leventhal, J. S., 1983. An interpretation of carbon and sulfur relationships in Black Sea sediments as indicators of environments of deposition. Geochim. Cosmochim. Acta, 47:133-137.

Matoba, Y., 1984. Paleoenvironment of the Sea of Japan. In Oertli, H. J. (Ed.), Benthos '83: 2nd Int. Symp. Benthic Foraminifera, 409-414.

Müller, P., Erlenkeuser, H., and von Grafenstein, R., 1983. Glacial-interglacial cycles in oceanic productivity inferred from organic-carbon contents in eastern North Atlantic sediment cores. In Thiede, J., and Suess, E. (Eds.), Coastal Upwelling: Its Sediment Record (Pt. B): New York (Plenum), 365-398.

Müller, P. J., and Suess, E., 1979. Productivity, sedimentation rate, and sedimentary organic matter in the oceans. I. Organic matter preservation. Deep-Sea Res. Part A, 26:1347-1362.

Oba, T., 1983. Oxygen isotope analysis. In Kobayashi, K. (Ed.), Preliminary Report of the Hakuho-maru Cruise KH 82-4, Tokyo, 140-141.

Oba, T., Kato, M., Kitazato, H., Koizumi, I., Omura, A., Sakai, T., and Takayama, T., 1991. Paleoenvironmental changes in the Japan Sea during the last 85,000 years. Paleoceanography, 6:499-518.

Ruddiman, W. F., and Janecek, T. R., 1989. Pliocene-Pleistocene biogenic and terrigenous fluxes at equatorial Atlantic Sites 662, 663, and 664. In Ruddiman, W. F., Sarnthein, M., et al., Proc. ODP, Sci. Results, 108: College Station, TX (Ocean Drilling Program), 211-240.

Sarnthein, M., Winn, K., and Zahn, R., 1987. Paleoproductivity of oceanic upwelling and the effect on atmospheric $\mathrm{CO}_{2}$ and climatic change during deglaciation times. In Berger, W. H., and Labeyrie, L. (Eds.), Abrupt Climatic Change: Dordrecht (Riedel Publ.), 311-337.

Scheidegger, K. F., and Krissek, L. A., 1983. Zooplankton and nekton: natural barriers to the seaward transport of suspended terrigenous particles off Peru. In Suess, E., and Thiede, J. (Eds.), Coastal Upwelling: Its Sediment Record (Pt. A): New York (Plenum), 303-336.

Shackleton, N. J., Backman, J., Zimmerman, H., Kent, D. V., Hall, M. A., Roberts, D. G., Schnitker, D., Baldauf, J. G., Desprairies, A., Homrighausen, R., Huddlestun, P., Keene, J. B., Kaltenback, A. J., Krumsiek, K.A.O., Morton, A. C., Murray, J. W., and Westberg-Smith, J., 1984. Oxygen isotope calibration of the onset of ice-rafting and history of glaciation in the North Atlantic region. Nature, 37:620-623.

Stach, E., Mackowsky, M. T., Teichmüller, M., Taylor, G. H., Chandra, D., and Teichmüller, R., 1982. Stach's Textbook of Coal Petrology: Berlin (Borntraeger Verlag).

Stein, R., 1985a. Late Neogene changes of paleoclimate and paleoproductivity off Northwest Africa (DSDP Site 397). Palaeogeogr., Palaeoclimatol., Palaeoecol., 49:47-59.

- 1985b. The post-Eocene sediment record of DSDP Site 366: implications for African climate and plate tectonic drift. In Kennett, J. P. (Ed.), The Miocene Ocean. Mem.-Geol. Soc. Am., 163:305-315.

, 1986. Surface-water paleo-productivity as inferred from sediments deposited in oxic and anoxic deep-water environments of the Mesozoic Atlantic Ocean. In Degens, E. T., Meyers, P. A., and Brassell, S. C. (Eds.), Biochemistry of Black Shales. Mitt. Geol. Paläontol. Inst. Univ. Hamburg, 60:55-70.

, 1991. Accumulation of organic carbon in marine sediments. Lect. Earth Sci., 34.

Stein, R., Littke, R., Stax, R., and Welte, D. H., 1989. Quantity, provenance, and maturity of organic matter at ODP Sites 645,646 , and 647: implications for reconstruction of paleoenvironments in Baffin Bay and Labrador Sea during Tertiary and Quaternary time. In Srivastava, S. P., Arthur, M. A., Clement, B., et al., Proc. ODP, Sci. Results, 105: College Station, TX (Ocean Drilling Program), 185-208.

Stein, R., Rullkötter, J., and Welte, D. H., 1986. Accumulation of organic-carbon-rich sediments in the Late Jurassic and Cretaceous Atlantic Ocean-a synthesis. Chem. Geol., 56:1-32.

Stein, R., ten Haven, H. L., Littke, R., Rullkötter, J., and Welte, D. H., 1989. Accumulation of marine and terrigenous organic carbon at upwelling Site 658 and nonupwelling Sites 657 and 659: implications for the reconstruction of paleoenvironments in the eastern subtropical Atlantic through late Cenozoic times. In Ruddiman, W. F., Sarnthein, M., et al., Proc. ODP, Sci. Results, 108: College Station, TX (Ocean Drilling Program), 361-385. 
Tamaki, K., 1985. Two modes of back-arc spreading. Geology, 13:475-478. -, 1988. Geological structure of the Japan Sea and its tectonic implications. Chishitsu Chosasho Geppo, 39:269-365.

Tamaki, K., Pisciotto, K., Allan, J., et al., 1990. Proc. ODP, Init. Repts., 127: College Station, TX (Ocean Drilling Program).

Tissot, B., Demaison, G., Masson, P., Delteil, J. R., and Combaz, A., 1980. Paleoenvironment and petroleum potential of mid-Cretaceous black shales in the Atlantic basins. AAPG Bull., 64:2051-2063.

Ujiie, H., and Ichikura, M., 1973. Holocene to uppermost Pleistocene planktonic foraminifers in a piston core from off the San'n district, Sea of Japan. Trans. Palaeontol. Soc. Jpn., New Ser., 9:137-150. yan Andel, T. H., Heath, G. R., and Moore, T. C., 1975. Cenozoic History and Paleoceanography of the Central Equatorial Pacific Ocean. Mem.-Geol. Soc. Am., 143.

Date of initial receipt: 4 April 1991

Date of acceptance: 22 November 1991

Ms 127/128B-146 
APPENDIX

TOC and carbonate contents and $\mathrm{C} / \mathrm{N}$ ratio of sediment samples from Site 798.

\begin{tabular}{cccccc}
\hline $\begin{array}{c}\text { Core, section, } \\
\text { interval }(\mathrm{cm})\end{array}$ & $\begin{array}{c}\text { Depth } \\
(\mathrm{mbsf})\end{array}$ & $\begin{array}{c}\text { Age } \\
(\mathrm{m} . \mathrm{y})\end{array}$ & $\begin{array}{c}\mathrm{TOC} \\
(\%)\end{array}$ & $\begin{array}{c}\mathrm{CaCO}_{3} \\
(\%)\end{array}$ & $\mathrm{C}_{\mathrm{org}} / \mathrm{N}$ \\
\hline
\end{tabular}

128-798A-

\begin{tabular}{|c|c|c|c|c|c|}
\hline $1 \mathrm{H}-1,39-41$ & 0.39 & 0.003 & 1.77 & 0.3 & 12.6 \\
\hline $1 \mathrm{H}-2,0-5$ & 1.50 & 0.013 & 1.14 & 5.7 & 9.5 \\
\hline $1 \mathrm{H}-2,46-51$ & 1.96 & 0.016 & 1.97 & 10.3 & 9.4 \\
\hline $1 \mathrm{H}-3,37-39$ & 3.37 & 0.028 & 1.97 & 10.1 & 9. \\
\hline $1 \mathrm{H}-4,38-45$ & 4.88 & 0.041 & 2.31 & 11.1 & 11. \\
\hline $1 \mathrm{H}-4,71-73$ & 5.21 & 0.043 & 1.49 & 9.5 & 11. \\
\hline $1 \mathrm{H}-4,82-84$ & 5.32 & 0.044 & 4.20 & 0.1 & 13. \\
\hline $1 \mathrm{H}-4,90-92$ & 5.40 & 0.045 & 4.60 & 0.1 & 11. \\
\hline $1 \mathrm{H}-4,96-98$ & 5.46 & 0.046 & 5.19 & 0.9 & 13. \\
\hline IH $-5,38-40$ & 6.38 & 0.053 & 2.82 & 2.3 & 11. \\
\hline IH- $6,38-44$ & 7.88 & 0.066 & 3.83 & 4.2 & 10. \\
\hline $2 \mathrm{H}-1,45-47$ & 9.75 & 0.081 & 2.45 & 8.0 & 12. \\
\hline $2 \mathrm{H}-2,46-51$ & 11.26 & 0.094 & 1.27 & 3.3 & \\
\hline $2 \mathrm{H}-3,0-5$ & 12.30 & 0.103 & 2.45 & 3.6 & 12. \\
\hline $2 \mathrm{H}-3,46-49$ & 12.76 & 0.106 & 1.34 & 9.4 & 12. \\
\hline $2 \mathrm{H}-3,123-125$ & 13.53 & 0.113 & 0.70 & 1.7 & 14 \\
\hline $2 \mathrm{H}-3,146-148$ & 13.76 & 0.115 & 1.13 & 7.4 & 10. \\
\hline $2 \mathrm{H}-4,4-9$ & 13.84 & 0.115 & 1.32 & 9.4 & 12. \\
\hline $3 \mathrm{H}-1,71-73$ & 19.01 & 0.158 & 4.26 & 0.0 & 10. \\
\hline $3 \mathrm{H}-2,19-21$ & 19.99 & 0.167 & 2.18 & 4.3 & 10. \\
\hline $3 \mathrm{H}-2,31-33$ & 20.11 & 0.168 & 2.89 & 8.7 & 17. \\
\hline $3 \mathrm{H}-2,43-45$ & 20.23 & 0.169 & 3.46 & 5.6 & 11 \\
\hline $3 \mathrm{H}-2,47-49$ & 20.27 & 0.169 & 1.68 & 3.1 & 11. \\
\hline $3 \mathrm{H}-2,49-51$ & 20.29 & 0.169 & 1.47 & 6.6 & 8 \\
\hline $3 \mathrm{H}-3,49-51$ & 21.79 & 0.182 & 1.96 & 1.3 & 10. \\
\hline $3 \mathrm{H}-4,49-51$ & 23.29 & 0.194 & 1.08 & 3.2 & 8. \\
\hline $3 \mathrm{H}-5,53-55$ & 24.83 & 0.207 & 5.25 & 0.0 & 11. \\
\hline $3 \mathrm{H}-6,49-51$ & 26.29 & 0.219 & 2.03 & 2.3 & 10. \\
\hline $4 \mathrm{H}-1,29-31$ & 27.59 & 0.230 & 1.83 & 23.2 & 11. \\
\hline $4 \mathrm{H}-2,29-31$ & 29.09 & 0.242 & 0.79 & 1.6 & 7. \\
\hline $4 \mathrm{H}-3,29-31$ & 30.59 & 0.255 & 1.17 & 3.8 & 9 \\
\hline $4 \mathrm{H}-4,47-49$ & 32.27 & 0.269 & 1.35 & 15.7 & 13 \\
\hline $4 H-4,59-63$ & 32.39 & 0.270 & 1.97 & 10.2 & 9 \\
\hline $4 \mathrm{H}-4,76-78$ & 32.56 & 0.271 & 2.78 & 0.0 & 18 \\
\hline $4 \mathrm{H}-4,84-86$ & 32.64 & 0.272 & 3.21 & 0.3 & 12 \\
\hline $4 \mathrm{H}-4,94-96$ & 32.74 & 0.273 & 4.16 & 0.0 & 13. \\
\hline $4 \mathrm{H}-5,0-5$ & 33.30 & 0.278 & 1.48 & 9.7 & 9. \\
\hline $5 \mathrm{H}-5,9-61$ & 33.89 & 0.282 & 2.11 & 14.2 & 11. \\
\hline $5 \mathrm{H}-1,95-97$ & 37.58 & 0.313 & 1.92 & 4.9 & 10 \\
\hline $5 \mathrm{H}-2,80-82$ & 38.83 & 0.324 & 1.75 & 26.8 & 10 \\
\hline $5 \mathrm{H}-3,49-51$ & 39.93 & 0.333 & 3.34 & 10.8 & 11 \\
\hline $5 \mathrm{H}-4,86-88$ & 41.66 & 0.347 & 2.56 & 6.7 & 10 \\
\hline $5 H-6,33-35$ & 43.94 & 0.365 & 1.38 & 7.9 & \\
\hline $5 \mathrm{H}-7,7-11$ & 45.09 & 0.374 & 2.37 & 24.7 & 11 \\
\hline $6 \mathrm{H}-1,58-60$ & 46.75 & 0.388 & 1.72 & 19.0 & 11 \\
\hline $6 \mathrm{H}-2,49-54$ & 48.10 & 0.398 & 1.56 & 23.7 & 10 \\
\hline $6 \mathrm{H}-3,7-9$ & 49.12 & 0.407 & 2.43 & 14.2 & 12 \\
\hline $6 \mathrm{H}-3,18-20$ & 49.23 & 0.407 & 2.98 & 7.5 & 13 \\
\hline $6 \mathrm{H}-3,28-30$ & 49.32 & 0.408 & 4.16 & 2.2 & 11 \\
\hline $6 \mathrm{H}-3,35-37$ & 49.39 & 0.409 & 1.67 & 23.6 & 11 \\
\hline $6 \mathrm{H}-3,46-48$ & 49.50 & 0.410 & 1.77 & 24.4 & 11 \\
\hline $6 \mathrm{H}-4,4-9$ & 50.52 & 0.418 & 2.44 & 21.2 & 11 \\
\hline $6 \mathrm{H}-5,69-71$ & 52.57 & 0.434 & 1.22 & 4.1 & \\
\hline $6 \mathrm{H}-6,84-89$ & 54.14 & 0.447 & 1.40 & 1.2 & \\
\hline $7 \mathrm{H}-1,49-51$ & 56.11 & 0.463 & 3.37 & 14.1 & 14 \\
\hline $7 \mathrm{H}-2,0-5$ & 56.96 & 0.473 & 2.52 & 0.6 & 11 \\
\hline $7 \mathrm{H}-2,130-135$ & 58.06 & 0.485 & 2.01 & 0.8 & 9 \\
\hline $7 \mathrm{H}-3,51-53$ & 58.66 & 0.492 & 3.16 & 0.0 & \\
\hline $7 \mathrm{H}-4,50-55$ & 59.92 & 0.505 & 1.02 & 10.5 & 9 \\
\hline $7 \mathrm{H}-5,50-52$ & 61.18 & 0.519 & 3.26 & 11.1 & 13 \\
\hline $7 \mathrm{H}-6,65-70$ & 62.57 & 0.535 & 2.08 & 20.9 & 10 \\
\hline $7 \mathrm{H}-7.66-68$ & 63.85 & 0.549 & 3.07 & 14.9 & 10 \\
\hline $7 \mathrm{H}-8,55-60$ & 65.02 & 0.561 & 2.30 & 10.6 & 10 \\
\hline $8 \mathrm{H}-2,0-5$ & 66.65 & 0.579 & 2.35 & 38.6 & 12 \\
\hline $8 \mathrm{H}-2,62-64$ & 67.21 & 0.586 & 1.18 & 30.5 & \\
\hline $8 \mathrm{H}-3,32-34$ & 68.29 & 0.598 & 2.44 & 32.7 & 11 \\
\hline $8 \mathrm{H}-4,80-82$ & 70.08 & 0.617 & 2.45 & 14.3 & 12 \\
\hline $8 \mathrm{H}-5,61-63$ & 71.26 & 0.630 & 1.20 & 15.1 & 8 \\
\hline $8 \mathrm{H}-6,38-40$ & 72.41 & 0.643 & 1.56 & 28.5 & 9 \\
\hline $8 \mathrm{H}-7,64-66$ & 73.99 & 0.660 & 1.23 & 25.1 & 8 \\
\hline $8 \mathrm{H}-8,45-47$ & 75.17 & 0.673 & 1.45 & 16.5 & 10 \\
\hline $9 \mathrm{H}-1,54-56$ & 75.30 & 0.675 & 1.29 & 20.1 & 11. \\
\hline
\end{tabular}

Appendix (continued).

\begin{tabular}{|c|c|c|c|c|c|}
\hline $\begin{array}{l}\text { Core, section, } \\
\text { interval }(\mathrm{cm})\end{array}$ & $\begin{array}{l}\text { Depth } \\
\text { (mbsf) }\end{array}$ & $\begin{array}{c}\text { Age } \\
\text { (m.y.) }\end{array}$ & $\begin{array}{l}\text { TOC } \\
(\%)\end{array}$ & $\begin{array}{c}\mathrm{CaCO}_{3} \\
(\%)\end{array}$ & $\mathrm{C}_{\text {org }} / \mathrm{N}$ \\
\hline $9 \mathrm{H}-2,29-31$ & 76.46 & 0.687 & 1.28 & 17.5 & 8.5 \\
\hline $9 \mathrm{H}-3,55-57$ & 78.09 & 0.705 & 1.42 & 17.4 & 8.9 \\
\hline $9 \mathrm{H}-4,0-5$ & 78.97 & 0.715 & 1.53 & 16.1 & 10.2 \\
\hline $9 \mathrm{H}-4,54-56$ & 79.47 & 0.720 & 1.86 & 12.8 & 9.3 \\
\hline $9 \mathrm{H}-5,54-56$ & 80.86 & 0.741 & 1.23 & 21.5 & 7.7 \\
\hline $9 \mathrm{H}-6,53-58$ & 82.24 & 0.771 & 0.91 & 6.5 & 5.4 \\
\hline $9 \mathrm{H}-7,54-56$ & 83.63 & 0.801 & 2.57 & 2.0 & 12.8 \\
\hline $10 \mathrm{H}-2,0-5$ & 85.74 & 0.839 & 4.22 & 2.3 & 11.7 \\
\hline $10 \mathrm{H}-2,34-36$ & 86.05 & 0.844 & 4.08 & 17.5 & 13.6 \\
\hline $10 \mathrm{H}-3,40-45$ & 87,44 & 0.866 & 3.81 & 2.9 & 11.2 \\
\hline $10 \mathrm{H}-4,44-46$ & 88.82 & 0.888 & 2.04 & 1.0 & 10.2 \\
\hline $10 \mathrm{H}-5,103-108$ & 90.69 & 0.913 & 3.06 & 0.9 & 11.3 \\
\hline $10 \mathrm{H}-6,45-47$ & 91.51 & 0.919 & 4.06 & 2.0 & 11.3 \\
\hline $10 \mathrm{H}-7,20-25$ & 92.63 & 0.927 & 1.82 & 2.2 & 8.3 \\
\hline $10 \mathrm{H}-7,128-133$ & 93.59 & 0.935 & 2.35 & 19.7 & 10.2 \\
\hline $10 \mathrm{H}-8,63-65$ & 94.36 & 0.940 & 1.28 & 17.5 & 9.1 \\
\hline $11 \mathrm{H}-1,97-99$ & 95.02 & 0.945 & 2.77 & 0.0 & 10.7 \\
\hline $11 \mathrm{H}-1,132-135$ & 95.36 & 0.947 & 3.73 & 0.0 & 12.9 \\
\hline $11 \mathrm{H}-2,0-5$ & 95.53 & 0.949 & 5.44 & 0.7 & 13.9 \\
\hline $11 \mathrm{H}-2,3-5$ & 95.56 & 0.949 & 5.31 & 0.0 & 11.8 \\
\hline $11 \mathrm{H}-2,80-84$ & 96.29 & 0.954 & 4.75 & 0.7 & 7.1 \\
\hline $11 \mathrm{H}-3,45-47$ & 97.38 & 0.962 & 1.51 & 23.2 & 10.1 \\
\hline $11 \mathrm{H}-3,94-96$ & 97.85 & 0.966 & 1.50 & 16.4 & 9.4 \\
\hline $11 \mathrm{H}-3,146-148$ & 98.34 & 0.969 & 3.70 & 20.1 & 13.7 \\
\hline $11 \mathrm{H}-4,2-4$ & 98.40 & 0.970 & 3.51 & 20.1 & 13.0 \\
\hline $11 \mathrm{H}-4,15-17$ & 98.52 & 0.971 & 1.57 & 14.7 & 9.2 \\
\hline $11 \mathrm{H}-4,86-90$ & 99.20 & 0.976 & 3.45 & 7.0 & 6.2 \\
\hline $11 \mathrm{H}-5,40-42$ & 100.19 & 0.983 & 1.95 & 20.0 & 7.8 \\
\hline $11 \mathrm{H}-6,102-107$ & 102.21 & 0.997 & 1.13 & 15.6 & 8.1 \\
\hline $12 \mathrm{H}-1,29-31$ & 104.05 & 1.010 & 2.50 & 0.0 & 11.4 \\
\hline $12 \mathrm{H}-2,30-35$ & 105.35 & 1.020 & 3.19 & 7.8 & 10.6 \\
\hline $12 \mathrm{H}-3,86-88$ & 107.13 & 1.033 & 2.60 & 0.0 & 11.3 \\
\hline $12 \mathrm{H}-5,0-5$ & 108.97 & 1.046 & 3.11 & 1.1 & 11.5 \\
\hline $12 \mathrm{H}-5,30-32$ & 109.23 & 1.048 & 4.16 & 1.0 & 11.9 \\
\hline $12 \mathrm{H}-6,25-29$ & 110.48 & 1.057 & 3.96 & 1.2 & 12.0 \\
\hline $12 \mathrm{H}-7,110-112$ & 112.51 & 1.071 & 2.74 & 8.3 & 13.7 \\
\hline $12 \mathrm{H}-8,0-5$ & 112.85 & 1.074 & 3.26 & 2.0 & 11.2 \\
\hline $12 \mathrm{H}-8,23-25$ & 113.05 & 1.075 & 1.48 & 1.8 & 8.2 \\
\hline $12 \mathrm{H}-8,30-34$ & 113.11 & 1.075 & 0.89 & 3.4 & 2.9 \\
\hline $12 \mathrm{H}-8,52-54$ & 113.30 & 1.077 & 1.99 & 0.0 & 9.0 \\
\hline $12 \mathrm{H}-8,62-64$ & 113.39 & 1.077 & 3.80 & 0.0 & 11.9 \\
\hline $12 \mathrm{H}-8,70-72$ & 113.46 & 1.078 & 4.00 & 0.0 & 12.1 \\
\hline $12 \mathrm{H}-8,75-77$ & 113.50 & 1.078 & 2.21 & 0.0 & 11.1 \\
\hline $13 \mathrm{H}-1,19-21$ & 113.58 & 1.079 & 1.76 & 1.0 & 11.0 \\
\hline $13 \mathrm{H}-2,98-103$ & 115.78 & 1.095 & 0.96 & 3.8 & 8.7 \\
\hline $13 \mathrm{H}-3,0-5$ & 116.27 & 1.098 & 1.89 & 12.7 & 11.8 \\
\hline $13 \mathrm{H}-3,50-52$ & 116.75 & 1.102 & 1.40 & 4.4 & 10.0 \\
\hline $13 \mathrm{H}-4,74-79$ & 118.42 & 1.114 & 2.56 & 11.6 & 10.7 \\
\hline $13 \mathrm{H}-5,51-53$ & 119.64 & 1.122 & 2.52 & 0.0 & 12.0 \\
\hline $13 \mathrm{H}-6,20-25$ & 120.78 & 1.130 & 2.31 & 4.8 & 10.0 \\
\hline $13 \mathrm{H}-7,45-47$ & 122.45 & 1.142 & 1.94 & 15.4 & 12.9 \\
\hline $14 \mathrm{H}-1,20-22$ & 123.28 & 1.148 & 2.82 & 8.9 & 14.1 \\
\hline $14 \mathrm{H}-2,30-34$ & 124.73 & 1.159 & 2.25 & 11.2 & 4.6 \\
\hline $14 \mathrm{H}-3,70-72$ & 126.45 & 1.171 & 3.13 & 4.8 & 11.6 \\
\hline $14 \mathrm{H}-4,62-66$ & 127.73 & 1.180 & 2.11 & 8.0 & 5.0 \\
\hline $14 \mathrm{H}-5,49-51$ & 128.97 & 1.189 & 1.11 & 6.1 & 7.9 \\
\hline $14 \mathrm{H}-6,49-53$ & 130.32 & 1.199 & 1.28 & 14.9 & 3.4 \\
\hline $14 \mathrm{H}-7,21-23$ & 131.43 & 1.207 & 1.67 & 5.5 & 15.2 \\
\hline $14 \mathrm{H}-8,22-26$ & 132.79 & 1.217 & 1.54 & 4.2 & 3.7 \\
\hline $15 \mathrm{H}-1,31-33$ & 133.06 & 1.218 & 2.10 & 5.8 & 11.7 \\
\hline $15 \mathrm{H}-2,35-39$ & 134.34 & 1.228 & 2.40 & 5.9 & 5.3 \\
\hline $15 \mathrm{H}-4,5-6$ & 136.58 & 1.244 & 3.12 & 6.2 & 12.0 \\
\hline $15 \mathrm{H}-4,30-34$ & 136.79 & 1.245 & 2.61 & 24.9 & 10.4 \\
\hline $15 \mathrm{H}-5,0-5$ & 137.79 & 1.252 & 1.79 & 4.4 & 10.5 \\
\hline $15 \mathrm{H}-5,30-32$ & 138.04 & 1.254 & 1.68 & 3.2 & 11.2 \\
\hline $15 \mathrm{H}-6,15-19$ & 139.16 & 1.262 & 4.95 & 4.8 & 10.1 \\
\hline $15 \mathrm{H}-7,30-32$ & 140.53 & 1.272 & 2.07 & 8.2 & 10.9 \\
\hline $15 \mathrm{H}-8,29-33$ & 141.77 & 1.281 & 1.69 & 5.7 & 4.0 \\
\hline
\end{tabular}

128-798B-

$\begin{array}{llllll}16 \mathrm{X}-2,45-50 & 144.53 & 1.301 & 1.75 & 12.8 & 8.0 \\ 16 \mathrm{X}-3,0-5 & 145.57 & 1.308 & 1.85 & 12.3 & 8.8 \\ 16 \mathrm{X}-4,48-53 & 147.53 & 1.322 & 1.80 & 13.8 & 8.6\end{array}$


APPENDIX (continued).

\begin{tabular}{|c|c|c|c|c|c|}
\hline $\begin{array}{l}\text { Core, section, } \\
\text { interval }(\mathrm{cm})\end{array}$ & $\begin{array}{l}\text { Depth } \\
\text { (mbsf) }\end{array}$ & $\begin{array}{c}\text { Age } \\
\text { (m.y.) }\end{array}$ & $\begin{array}{l}\text { TOC } \\
(\%)\end{array}$ & $\begin{array}{c}\mathrm{CaCO}_{3} \\
(\%)\end{array}$ & $\mathrm{C}_{\text {org }} / \mathrm{N}$ \\
\hline $16 \mathrm{X}-6,34-39$ & 150.36 & 1.343 & 1.60 & 9.8 & 8.4 \\
\hline $17 X-2,0-5$ & 153.72 & 1.367 & 1.74 & 9.3 & 9.2 \\
\hline $17 X-2,48-54$ & 154.18 & 1.370 & 1.76 & 11.3 & 8.4 \\
\hline $17 X-4,28-35$ & 156.83 & 1.389 & 1.68 & 9.4 & 7.6 \\
\hline $17 X-6,39-44$ & 159.78 & 1.410 & 1.57 & 9.8 & 7.8 \\
\hline $18 X-5,149-150$ & 169.39 & 1.479 & 1.77 & 11.6 & 9.3 \\
\hline $19 X-2,60-65$ & 173.70 & 1.510 & 1.67 & 10.3 & 8.8 \\
\hline $19 \times-4,50-55$ & 176.60 & 1.531 & 2.21 & 1.7 & 10.0 \\
\hline $19 X-6,60-65$ & 179.70 & 1.553 & 1.25 & 5.7 & 6.9 \\
\hline $20 X-1,39-41$ & 181.62 & 1.567 & 1.66 & 1.7 & 8.7 \\
\hline $20 \mathrm{X}-2,40-45$ & 182.86 & 1.576 & 1.12 & 4.9 & 7.5 \\
\hline $20 X-4,103-108$ & 185.85 & 1.597 & 1.55 & 6.1 & 7.8 \\
\hline $20 X-5,60-65$ & 186.73 & 1.603 & 1.11 & 7.1 & 7.4 \\
\hline $21 X-2,45-48$ & 192.95 & 1.648 & 1.37 & 2.3 & 8.6 \\
\hline $21 X-2,77-79$ & 193.27 & 1.650 & 1.57 & 1.8 & 8.3 \\
\hline $21 X-3,59-61$ & 194.59 & 1.660 & 1.43 & 3.1 & 7.9 \\
\hline $21 X-4,39-44$ & 195.89 & 1.674 & 1.22 & 1.9 & 7.2 \\
\hline $21 X-6,19-24$ & 198.69 & 1.704 & 1.64 & 3.9 & 9.1 \\
\hline $21 \times-6.59-64$ & 199.09 & 1.709 & 0.99 & 3.3 & 2.8 \\
\hline $21 X-7,0-5$ & 200.00 & 1.718 & 1.51 & 8.2 & 9.4 \\
\hline $21 X-7,77-79$ & 200.77 & 1.727 & 1.68 & 5.1 & 9.9 \\
\hline $22 X-2,30-35$ & 202.07 & 1.741 & 2.67 & 0.6 & 4.9 \\
\hline $22 X-4,17-22$ & 204.41 & 1.766 & 3.10 & 0.6 & 10.3 \\
\hline $22 \mathrm{X}-6,90-92$ & 207.46 & 1.799 & 2.68 & 0.0 & 11.2 \\
\hline $22 X-7,42-47$ & 208.29 & 1.808 & 2.40 & 1.3 & 9.2 \\
\hline $22 \times-8,77-79$ & 209.80 & 1.825 & 2.29 & 0.0 & 10.4 \\
\hline $23 \mathrm{X}-2,25-29$ & 211.77 & 1.846 & 1.21 & 7.1 & 2.2 \\
\hline $23 \mathrm{X}-5,120-125$ & 216.35 & 1.890 & 1.60 & 2.2 & 8.0 \\
\hline $23 \times-7,60-65$ & 218.36 & 1.905 & 2.71 & 1.0 & 9.7 \\
\hline $23 \mathrm{X}-8,34-36$ & 219.40 & 1.912 & 1.98 & 0.0 & 9.0 \\
\hline $24 X-2,49-54$ & 221.95 & 1.930 & 2.94 & 0.6 & 10.9 \\
\hline $24 X-3,0-5$ & 222.94 & 1.937 & 3.03 & 0.7 & 10.1 \\
\hline $24 X-4,49-54$ & 224.89 & 1.951 & 2.27 & 0.5 & 9.1 \\
\hline $24 X-6,43-48$ & 227.77 & 1.971 & 2.81 & 0.7 & 10.0 \\
\hline $24 X-7,22-24$ & 229.04 & 1.980 & 2.89 & 0.0 & 12.0 \\
\hline $25 X-2,68-73$ & 231.88 & 2.000 & 1.46 & 1.6 & 7.0 \\
\hline $25 X-3,68-70$ & 233.38 & 2.010 & 1.45 & 0.7 & 8.1 \\
\hline $25 X-4,63-67$ & 234.83 & 2.021 & 1.77 & 1.2 & 8.8 \\
\hline $27 X-1,66-68$ & 249.65 & 2.125 & 1.57 & 0.0 & 9.8 \\
\hline $27 \mathrm{X}-2,38-43$ & 250.86 & 2.134 & 1.70 & 1.5 & 8.5 \\
\hline $27 X-3,115-118$ & 253.11 & 2.149 & 2.37 & 0.6 & 10.8 \\
\hline $27 X-4,0-5$ & 253.46 & 2.152 & 1.81 & 0.7 & 10.1 \\
\hline $27 \times-4,15-20$ & 253.60 & 2.153 & 1.76 & 0.9 & 8.8 \\
\hline $27 X-6,95-100$ & 257.37 & 2.179 & 1.46 & 1.5 & 8.1 \\
\hline $28 X-2,0-5$ & 259.98 & 2.198 & 2.61 & 0.8 & 11.3 \\
\hline $28 X-4,31-35$ & 262.82 & 2.218 & 2.09 & 0.7 & 10.4 \\
\hline $28 X-5,29-31$ & 264.09 & 2.227 & 1.80 & 0.0 & 9.0 \\
\hline $28 X-6,27-33$ & 265.35 & 2.236 & 1.79 & 0.7 & 8.9 \\
\hline $29 \mathrm{X}-1,31-33$ & 268.55 & 2.258 & 2.41 & 0.0 & 10.5 \\
\hline $29 X-3,31-33$ & 270.95 & 2.275 & 2.77 & 0.0 & 12.0 \\
\hline $29 \mathrm{X}-4,30-35$ & 272.15 & 2.283 & 2.81 & 0.8 & 10.0 \\
\hline $29 X-5,31-33$ & 273.36 & 2.292 & 1.92 & 0.0 & 9.6 \\
\hline $29 X-6,35-40$ & 274.59 & 2.301 & 2.60 & 1.2 & 9.6 \\
\hline $30 \times-3,0-5$ & 280.20 & 2.340 & 1.39 & 1.3 & 7.3 \\
\hline $30 \times-5,100-102$ & 284.20 & 2.368 & 0.88 & 1.1 & 5.9 \\
\hline $30 X-6,100-102$ & 285.70 & 2.379 & 2.59 & 0.0 & 9.6 \\
\hline $31 \times-2,0-5$ & 287.76 & 2.393 & 2.05 & 0.4 & 10.2 \\
\hline $31 X-2,30-35$ & 288.03 & 2.395 & 1.79 & 0.8 & 10.5 \\
\hline $31 X-4,55-60$ & 290.99 & 2.416 & 0.98 & 0.4 & 5.8 \\
\hline $31 X-6,30-35$ & 293.48 & 2.434 & 2.04 & 0.7 & 10.7 \\
\hline $31 X-7,86-88$ & 295.36 & 2.447 & 3.07 & 0.0 & 11.0 \\
\hline $31 X-8,30-35$ & 296.21 & 2.453 & 2.42 & 0.8 & 10.5 \\
\hline $32 X-2,40-45$ & 297.54 & 2.462 & 1.56 & 0.5 & 9.2 \\
\hline $32 X-3,20-22$ & 298.60 & 2.470 & 1.35 & 0.0 & 7.1 \\
\hline $32 X-4,70-75$ & 300.22 & 2.488 & 1.27 & 0.9 & 8.5 \\
\hline $32 X-5,20-22$ & 301.04 & 2.498 & 1.47 & 0.0 & 8.6 \\
\hline $32 X-8,60-64$ & 305.02 & 2.543 & 1.33 & 2.7 & 4.6 \\
\hline $33 \mathrm{X}-1,20-22$ & 305.89 & 2.553 & 1.91 & 0.0 & 7.6 \\
\hline $33 X-3,110-115$ & 309.58 & 2.595 & 1.92 & 0.5 & 9.1 \\
\hline $33 \times-4,60-65$ & 310.53 & 2.606 & 1.81 & 0.3 & 9.1 \\
\hline $33 X-5,19-21$ & 311.56 & 2.618 & 2.25 & 0.0 & 10.7 \\
\hline $33 X-6,30-35$ & 313.09 & 2.635 & 1.95 & 0.8 & 8.9 \\
\hline $34 X-1,90-92$ & 316.20 & 2.671 & 1.40 & 1.5 & 6.1 \\
\hline $34 \mathrm{X}-2,84-89$ & 317.64 & 2.687 & 1.65 & 0.7 & 7.5 \\
\hline $34 X-4,5-0$ & 319.85 & 2.713 & 1.70 & 0.7 & 8.1 \\
\hline $34 X-5,39-41$ & 321.69 & 2.734 & 1.73 & 0.2 & 8.7 \\
\hline
\end{tabular}

APPENDIX (continued).

\begin{tabular}{|c|c|c|c|c|c|}
\hline $\begin{array}{l}\text { Core, section, } \\
\text { interval }(\mathrm{cm})\end{array}$ & $\begin{array}{l}\text { Depth } \\
\text { (mbsf) }\end{array}$ & $\begin{array}{c}\text { Age } \\
\text { (m.y.) }\end{array}$ & $\begin{array}{l}\text { TOC } \\
(\%)\end{array}$ & $\begin{array}{c}\mathrm{CaCO}_{3} \\
(\%)\end{array}$ & $\mathrm{C}_{\text {org }} / \mathrm{N}$ \\
\hline $34 \mathrm{X}-6,24-29$ & 323.04 & 2.749 & 1.56 & 1.1 & 7.3 \\
\hline $35 \times-2,15-19$ & 326.65 & 2.790 & 1.19 & 1.3 & 6.0 \\
\hline $35 \mathrm{X}-3,39-41$ & 328.39 & 2.810 & 1.26 & 8.1 & 6.6 \\
\hline $35 X-4,40-45$ & 329.90 & 2.827 & 1.91 & 5.0 & 9.1 \\
\hline $35 X-5,40-42$ & 331.40 & 2.845 & 2.20 & 0.0 & 10.5 \\
\hline $35 X-6,60-65$ & 333.10 & 2.864 & 1.54 & 0.7 & 8.6 \\
\hline $35 \times-7,5-7$ & 334.05 & 2.875 & 1.98 & 3.9 & 9.0 \\
\hline $35 X-7,13-18$ & 334.13 & 2.876 & 1.94 & 4.4 & 5.0 \\
\hline $36 \mathrm{X}-1,80-82$ & 335.40 & 2.890 & 1.56 & 2.1 & 8.2 \\
\hline $36 \mathrm{X}-2,20-22$ & 336.30 & 2.901 & 1.49 & 2.1 & 9.3 \\
\hline $36 X-2,75-78$ & 336.85 & 2.907 & 1.25 & 2.2 & 8.9 \\
\hline $36 \mathrm{X}-3,14-16$ & 337.74 & 2.917 & 1.38 & 2.3 & 8.1 \\
\hline $37 X-1,60-62$ & 344.90 & 2.999 & 1.24 & 1.4 & 6.9 \\
\hline $37 X-2,46-48$ & 346.26 & 3.014 & 1.30 & 2.7 & 8.1 \\
\hline $38 \mathrm{X}-1,17-19$ & 354.07 & 3.104 & 1.29 & 2.6 & 6.8 \\
\hline $38 X-2,40-42$ & 355.80 & 3.123 & 1.42 & 1.3 & 7.9 \\
\hline $38 X-4,31-33$ & 358.71 & 3.157 & 1.92 & 0.8 & 9.6 \\
\hline $38 \mathrm{X}-4,140-150$ & 359.80 & 3.169 & 1.46 & 0.6 & 9.7 \\
\hline $38 \mathrm{X}-6,58-60$ & 361.98 & 3.194 & 1.65 & 2.0 & 8.2 \\
\hline $39 \mathrm{X}-3,32-34$ & 366.92 & 3.251 & 1.53 & 0.2 & 8.1 \\
\hline $39 X-4,85-87$ & 368.95 & 3.274 & 1.53 & 1.6 & 8.5 \\
\hline $39 X-5,0-5$ & 369.60 & 3.281 & 1.28 & 1.5 & 3.8 \\
\hline $39 X-5,92-94$ & 370.52 & 3.292 & 1.41 & 1.2 & 7.0 \\
\hline $39 X-6,127-129$ & 372.37 & 3.313 & 1.14 & 1.8 & 8.1 \\
\hline $40 X-1,24-26$ & 373.44 & 3.325 & 1.89 & 0.0 & 9.4 \\
\hline $40 X-2,23-25$ & 374.93 & 3.342 & 1.80 & 0.8 & 9.5 \\
\hline $40 X-2,70-73$ & 375.40 & 3.347 & 1.91 & 0.7 & 10.6 \\
\hline $40 \times-4,131-133$ & 379.01 & 3.389 & 2.12 & 0.0 & 8.8 \\
\hline $40 X-4,140-144$ & 379.10 & 3.390 & 2.05 & 0.3 & 5.3 \\
\hline $40 X-5,31-33$ & 379.51 & 3.394 & 2.25 & 0.8 & 11.2 \\
\hline $41 X-3,60-65$ & 386.40 & 3.473 & 1.87 & 0.7 & 9.8 \\
\hline $41 X-4,60-62$ & 387.85 & 3.490 & 1.90 & 0.2 & 9.5 \\
\hline $41 X-5,61-66$ & 389.32 & 3.507 & 1.60 & 1.5 & 8.4 \\
\hline $41 X-5,75-77$ & 389.45 & 3.508 & 0.69 & 0.8 & 7.7 \\
\hline $41 X-6,20-22$ & 390.38 & 3.519 & 1.93 & 0.0 & 8.4 \\
\hline $41 X-6,31-33$ & 390.48 & 3.520 & 2.42 & 1.0 & 12.7 \\
\hline $42 X-2,19-21$ & 394.19 & 3.562 & 1.30 & 0.5 & 8.1 \\
\hline $42 X-3,20-25$ & 395.70 & 3.579 & 1.32 & 1.5 & 9.4 \\
\hline $42 X-5,135-140$ & 399.85 & 3.627 & 1.21 & 3.4 & 8.1 \\
\hline $42 X-6,75-77$ & 400.75 & 3.637 & 1.06 & 1.9 & 9.6 \\
\hline $42 X-7,19-24$ & 401.69 & 3.648 & 1.04 & 1.4 & 7.4 \\
\hline $42 X-7,88-90$ & 402.38 & 3.656 & 1.16 & 2.2 & 10.5 \\
\hline $43 \mathrm{X}-2,80-85$ & 404.50 & 3.680 & 1.05 & 3.4 & 7.5 \\
\hline $43 X-4,50-55$ & 407.20 & 3.711 & 0.76 & 0.8 & 6.9 \\
\hline $43 X-6,20-25$ & 409.90 & 3.742 & 1.37 & 2.0 & 10.5 \\
\hline $44 X-1,105-107$ & 412.77 & 3.775 & 1.20 & 0.0 & 7.5 \\
\hline $44 X-2,40-45$ & 413.56 & 3.784 & 0.51 & 1.1 & 3.9 \\
\hline $44 X-2,70-71$ & 413.84 & 3.787 & 0.22 & 0.4 & 1.2 \\
\hline $44 X-7,50-55$ & 420.62 & 3.864 & 0.90 & 1.2 & 7.5 \\
\hline $45 X-3,70-73$ & 424.31 & 3.906 & 0.92 & 0.7 & 9.2 \\
\hline $45 X-5,132-134$ & 427.07 & 3.938 & 1.10 & 0.8 & 6.5 \\
\hline $45 X-6,120-125$ & 428.12 & 3.950 & 1.60 & 1.7 & 9.4 \\
\hline $45 X-7,31-33$ & 428.58 & 3.955 & 1.32 & 1.7 & 7.8 \\
\hline $46 \mathrm{X}-1,50-52$ & 431.59 & 3.990 & 1.55 & 0.7 & 9.7 \\
\hline $46 \times-3,110-112$ & 435.12 & 4.030 & 1.01 & 0.8 & 7.2 \\
\hline $46 X-4,66-68$ & 436.16 & 4.042 & 1.14 & 0.0 & 8.1 \\
\hline $46 \mathrm{X}-5,43-45$ & 437.40 & 4.056 & 1.36 & 0.5 & 9.7 \\
\hline $46 \mathrm{X}-6,112-114$ & 439.55 & 4.081 & 1.40 & 1.2 & 10.0 \\
\hline $47 \mathrm{X}-1,0-5$ & 440.80 & 4.095 & 1.42 & 0.5 & 3.6 \\
\hline $47 \mathrm{X}-1,26-28$ & 441.06 & 4.098 & 1.90 & 1.0 & 11.9 \\
\hline $47 X-2,7-9$ & 442.35 & 4.113 & 1.47 & 0.6 & 9.2 \\
\hline $47 X-3,74-76$ & 444.50 & 4.137 & 1.40 & 0.6 & 7.8 \\
\hline $47 X-4,44-46$ & 445.69 & 4.151 & 1.28 & 1.3 & 8.0 \\
\hline $47 X-6,80-82$ & 449.02 & 4.189 & 1.59 & 1.3 & 9.9 \\
\hline $48 \mathrm{X}-1,44-46$ & 450.84 & 4.210 & 1.20 & 0.8 & 8.6 \\
\hline $47 X-8,0-5$ & 451.20 & 4.214 & 0.64 & 3.2 & 2.1 \\
\hline $47 X-8,5-10$ & 451.25 & 4.214 & 0.99 & 0.9 & 6.2 \\
\hline $48 X-2,0-5$ & 451.90 & 4.222 & 1.19 & 0.8 & 10.8 \\
\hline $48 \mathrm{X}-2,21-23$ & 452.11 & 4.224 & 1.42 & 0.8 & 9.5 \\
\hline $48 X-4,62-64$ & 455.52 & 4.263 & 1.56 & 1.2 & 10.4 \\
\hline $48 X-5,97-99$ & 457.37 & 4.284 & 1.31 & 2.1 & 9.4 \\
\hline $48 \times-6,0-5$ & 457.90 & 4.290 & 1.29 & 1.3 & 9.2 \\
\hline $48 \mathrm{X}-6,25-30$ & 458.15 & 4.293 & 0.96 & 1.3 & 6.9 \\
\hline $49 \mathrm{X}-1,63-65$ & 460.71 & 4.322 & 0.60 & 0.8 & 6.0 \\
\hline $49 \mathrm{X}-2,110-112$ & 462.62 & 4.344 & 0.94 & 1.3 & 6.3 \\
\hline $49 X-3,76-78$ & 463.75 & 4.357 & 0.80 & 0.9 & 6.7 \\
\hline
\end{tabular}


APPENDIX (continued).

\begin{tabular}{|c|c|c|c|c|c|}
\hline $\begin{array}{l}\text { Core, section, } \\
\text { interval }(\mathrm{cm})\end{array}$ & $\begin{array}{l}\text { Depth } \\
\text { (mbsf) }\end{array}$ & $\begin{array}{l}\text { Age } \\
\text { (m.y.) }\end{array}$ & $\begin{array}{l}\text { TOC } \\
(\%)\end{array}$ & $\begin{array}{c}\mathrm{CaCO}_{3} \\
(\%)\end{array}$ & $\mathrm{C}_{\text {org }} / \mathrm{N}$ \\
\hline $49 X-3,131-133$ & 464.28 & 4.363 & 1.40 & 0.9 & 11.7 \\
\hline $49 X-4,112-114$ & 465.56 & 4.378 & 0.59 & 1.5 & 5.9 \\
\hline $49 X-6,110-112$ & 468.45 & 4.411 & 0.98 & 1.7 & 7.0 \\
\hline $49 X-7,50-55$ & 469.32 & 4.421 & 0.88 & 1.3 & 7.3 \\
\hline $50 X-1,75-77$ & 470.45 & 4.434 & 1.00 & 0.3 & 7.7 \\
\hline $50 \times-2,110-112$ & 472.30 & 4.455 & 1.01 & 0.7 & 8.4 \\
\hline $50 X-3,145-150$ & 474.15 & 4.476 & 1.30 & 1.1 & 9.3 \\
\hline $51 X-3,84-86$ & 483.24 & 4.580 & 2.03 & 0.0 & 11.3 \\
\hline $51 X-4,0-5$ & 483.90 & 4.587 & 1.67 & 1.3 & 5.8 \\
\hline $51 X-4,108-110$ & 484.98 & 4.600 & 1.55 & 1.7 & 10.3 \\
\hline $51 X-5,21-23$ & 485.61 & 4.607 & 1.46 & 1.8 & 10.4 \\
\hline $51 X-6,21-23$ & 487.11 & 4.624 & 1.70 & 1.0 & 10.0 \\
\hline $51 X-6,86-88$ & 487.76 & 4.632 & 1.43 & 2.3 & 8.9 \\
\hline $52 X-1,0-5$ & 489.00 & 4.646 & 0.90 & 1.7 & 3.5 \\
\hline $52 X-1,19-21$ & 489.19 & 4.548 & 1.00 & 11.4 & 7.1 \\
\hline $52 X-2,17-19$ & 490.65 & 4.665 & 3.02 & 0.0 & 12.1 \\
\hline $52 X-3,93-95$ & 492.89 & 4.690 & 2.08 & 0.0 & 10.9 \\
\hline $52 X-4,94-96$ & 494.39 & 4.707 & 2.65 & 2.0 & 11.5 \\
\hline $52 X-5,91-93$ & 495.84 & 4.724 & 3.00 & 2.0 & 12.5 \\
\hline $52 X-6,40-42$ & 496.82 & 4.735 & 3.33 & 1.0 & 12.8 \\
\hline $52 X-6,128-130$ & 497.69 & 4.745 & 2.60 & 0.3 & 11.3 \\
\hline $53 \mathrm{X}-1,0-5$ & 498.70 & 4.757 & 2.29 & 3.3 & 11.4 \\
\hline $53 \mathrm{X}-1,121-123$ & 499.91 & 4.770 & 2.30 & 0.0 & 12.1 \\
\hline $53 X-3,0-5$ & 501.70 & 4.791 & 3.53 & 0.4 & 9.1 \\
\hline $53 X-3,11-12$ & 501.81 & 4.792 & 0.31 & 0.2 & 0.1 \\
\hline $53 X-4,50-53$ & 503.70 & 4.814 & 4.13 & 0.4 & 14.2 \\
\hline $53 X-4,56-58$ & 503.76 & 4.814 & 3.92 & 0.2 & 14.5 \\
\hline $53 X-5,8-10$ & 504.78 & 4.826 & 3.53 & 0.0 & 12.6 \\
\hline $54 X-1,54-56$ & 508.78 & 4.872 & 4.10 & 0.9 & 14.1 \\
\hline $54 \mathrm{X}-2,56-58$ & 510.11 & 4.887 & 2.70 & 0.8 & 14.2 \\
\hline $54 \mathrm{X}-2,103-105$ & 510.53 & 4.892 & 6.09 & 0.0 & 13.8 \\
\hline $54 X-3,87-89$ & 511.71 & 4.905 & 5.67 & 0.0 & 16.2 \\
\hline $54 X-3,123-125$ & 512.03 & 4.909 & 6.44 & 0.0 & 13.7 \\
\hline $54 X-4,131-133$ & 513.42 & 4.925 & 4.90 & 0.6 & 15.3 \\
\hline $54 X-5,92-94$ & 514.40 & 4.936 & 3.70 & 0.2 & 13.7 \\
\hline $54 X-7,0-5$ & 516.23 & 4.957 & 2.62 & 1.7 & 7.9 \\
\hline $54 X-8,55-60$ & 518.04 & 4.978 & 3.35 & 2.7 & 9.6 \\
\hline
\end{tabular}

